Review

\title{
Lipids in the intensive care unit: Recommendations from the ESPEN Expert Group ${ }^{\text {is }}$
}

\author{
Philip C. Calder a, b, *, Michael Adolph ${ }^{\text {c }}$, Nicolaas E. Deutz ${ }^{\mathrm{d}}$, Teodoro Grau ${ }^{\mathrm{e}}$, \\ Jacqueline K. Innes ${ }^{a}$, Stanislaw Klek ${ }^{\mathrm{f}}$, Shaul Lev ${ }^{\mathrm{g}}$, Konstantin Mayer ${ }^{\mathrm{h}}$, \\ Adina T. Michael-Titus ${ }^{\mathrm{i}}$, Lorenzo Pradelli ${ }^{\mathrm{j}}$, Mark Puder ${ }^{\mathrm{k}}$, Hester Vlaardingerbroek ${ }^{1}$, \\ Pierre Singer ${ }^{g}$ \\ ${ }^{a}$ Human Development and Health Academic Unit, Faculty of Medicine, University of Southampton, Southampton SO16 6YD, United Kingdom \\ ${ }^{\mathrm{b}}$ National Institute for Health Research Southampton Biomedical Research Centre, University Hospital Southampton NHS Foundation Trust and University \\ of Southampton, Southampton SO16 6YD, United Kingdom \\ ${ }^{c}$ Department of Anesthesiology and Intensive Care Medicine, Nutrition Support Team, University Clinic Tübingen, 72074 Tübingen, Germany \\ ${ }^{\mathrm{d}}$ Center for Translational Research in Aging \& Longevity, Department of Health and Kinesiology, Texas A\&M University, College Station, TX 77843, USA \\ e Hospital Universitario Doce de Octubre, Madrid, Spain \\ ${ }^{\mathrm{f}}$ General and Oncology Surgery Unit, Intestinal Failure Center, Stanley Dudrick's Memorial Hospital, Skawina, Poland \\ ${ }^{g}$ Department of General Intensive Care and Institute for Nutrition Research, Rabin Medical Center, Hasharon Hospital and Sackler School of Medicine, Tel \\ Aviv University, Tel Aviv, Israel \\ h Department of Internal Medicine, Med. Clinik II, University Hospital Giessen and Marburg, 35392 Giessen, Germany \\ i Centre for Neuroscience and Trauma, The Blizard Institute, Barts and The London School of Medicine and Dentistry, Queen Mary University of London, \\ London E1 2AT, United Kingdom \\ ${ }^{\mathrm{j}}$ AdRes Health Economics and Outcomes Research, 10121 Turin, Italy \\ ${ }^{\mathrm{k}}$ Vascular Biology Program and the Department of Surgery, Boston Children's Hospital, Boston, MA 02115, USA \\ ${ }^{1}$ Department of Pediatrics, Emma Children's Hospital, Academic Medical Center, Amsterdam, The Netherlands
}

\section{A R T I C L E I N F O}

\section{Article history:}

Received 5 July 2017

Accepted 31 August 2017

\section{Keywords:}

Lipid emulsion

Enteral nutrition

Parenteral nutrition

Sepsis

Critical illness

Surgery

\begin{abstract}
S U M M A R Y
This article summarizes the presentations given at an ESPEN Workshop on "Lipids in the ICU" held in Tel Aviv, Israel in November 2014 and subsequent discussions and updates. Lipids are an important component of enteral and parenteral nutrition support and provide essential fatty acids, a concentrated source of calories and building blocks for cell membranes. Whilst linoleic acid-rich vegetable oil-based enteral and parenteral nutrition is still widely used, newer lipid components such as medium-chain triglycerides and olive oil are safe and well tolerated. Fish oil (FO)-enriched enteral and parenteral nutrition appears to be well tolerated and confers additional clinical benefits, particularly in surgical patients, due to its anti-inflammatory and immune-modulating effects. Whilst the evidence base is not conclusive, there appears to be a potential for FO-enriched nutrition, particularly administered perioperatively, to reduce the rate of complications and intensive care unit (ICU) and hospital stay in surgical ICU patients. The evidence for FO-enriched nutrition in non-surgical ICU patients is less clear regarding its clinical benefits and additional, well-designed large-scale clinical trials need to be conducted in this area. The ESPEN Expert Group supports the use of olive oil and FO in nutrition support in surgical and non-surgical ICU patients but considers that further research is required to provide a more robust evidence base.
\end{abstract}

๑ 2017 Elsevier Ltd and European Society for Clinical Nutrition and Metabolism. All rights reserved.

\footnotetext{
Based upon the ESPEN Workshop "Lipids in the ICU" held in Tel Aviv, Israel on 23 and 24 November 2014.

* Corresponding author. Faculty of Medicine, University of Southampton, IDS Building, MP887 Southampton General Hospital, Tremona Road, Southampton SO16 6YD, United Kingdom.

E-mail address: pcc@soton.ac.uk (P.C. Calder).
}

\section{Nutrition support of the critically ill patient}

Patients in an intensive care unit (ICU) are heterogeneous and include surgical and medical patients, mechanically-ventilated or non-ventilated, obese or undernourished, preterm infants to older adults, requiring either short-term or long-term intensive care [1]. Nutrition support is critical in maintaining homeostasis in the ICU 
patient and to provide nutrients for the maintenance of lean body mass as well as repair and maintenance of organ function and support of defense and healing processes.

Enteral nutrition (EN) comprises specialized liquid nutrition delivered through a nasogastric or post-pyloric feeding tube into the stomach or small intestine (duodenum/jejunum), respectively [2]. The European Society for Clinical Nutrition and Metabolism (ESPEN) guidelines recommend that EN should be given to all ICU patients who are not expected to be taking a full oral diet within three days [3].

Whilst ESPEN acknowledges that there are no definitive data supporting the early use of EN in terms of clinical outcomes, its guidelines recommend that hemodynamically stable critically ill patients who have a functioning gastrointestinal tract should be fed early ( $<24 \mathrm{~h}$ ) using an appropriate amount of feed [3]. Early initiation of EN is also recommended by the American Society for Parenteral and Enteral Nutrition (ASPEN) and the Canadian Society of Critical Care Medicine (SCCM) [4], as well as the European Society of Intensive Care Medicine (ESICM) [5]. Administration of early EN in critically ill patients appears to also have a positive economic impact, with analysis suggesting that it is associated with significantly reduced costs relating to reduction in ICU stay and duration of mechanical ventilation compared with standard care [6].

There are a number of nutritional and non-nutritional benefits associated with early EN feeding. These include the maintenance of lean body mass, gut integrity, mucosal associated lymphoid tissue and muscle function, together with attenuation of oxidative stress [7]. Studies performed after the publishing of ESPEN guidelines have demonstrated positive clinical outcomes with early EN administration, such as reduction in duration of mechanical ventilation, reduction in length of ICU stay and higher survival rates in critically ill mechanically-ventilated patients, compared with delayed EN administration [8,9]. Furthermore, two metaanalyses investigating early EN $(<24 \mathrm{~h})$ in critically ill and trauma patients reported a significant mortality reduction versus standard care and a significant reduction in incidence of pneumonia $[10,11]$.

The macronutrient content of several EN formulas used in clinical practice or in experimental studies is detailed in Table 1 ; it is evident that these differ greatly in content of macronutrients and in individual bioactive nutrients including glutamine, arginine and omega-3 fatty acids. Hence the metabolic, physiologic and clinical impact of different EN formulas will differ.

Parenteral nutrition (PN) is nutrition support provided through intravenous administration of nutrients such as amino acids, glucose, lipids (as emulsions), electrolytes, vitamins and trace elements. PN can be provided through a central venous line or through a peripheral intravenous line [12]. The ESPEN Guidelines for
Parenteral Nutrition in Intensive Care recommend that all patients who are not expected to be on normal nutrition within 3 days should receive PN within 24-48 h, if EN is contraindicated or if they cannot tolerate EN [13]. Furthermore, supplementary PN may also be initiated alongside EN in critically ill patients to help achieve energy and protein targets.

In terms of the safety of PN compared with EN in critically ill patients, whilst PN is associated with a lower mortality risk, particularly when compared to late EN, it has an increased risk of infectious complications [14,15]. Compared to standard care (oral diet when tolerated plus iv dextrose) in malnourished patients, EN appears to be associated with a lower risk of infection, whilst PN confers a lower risk of mortality as well as infection [16]. Supplemental PN may have clinical benefits in addition to reaching nutritional targets earlier, such as reduced risk of nosocomial infections when initiated on days 4-8 alongside EN compared to EN alone [17]. However, a recent large scale multi-center randomized controlled study compared EN to PN and found no significant difference in mortality and infectious complications [18].

\section{Lipids in enteral and parenteral nutrition}

Lipids are used in enteral and parenteral nutrition primarily due to their high caloric content and are thus a good concentrated source of energy. As such, they lower the amount of carbohydrate that needs to be provided as part of the nutrition support. Lipids also provide the building blocks for cell membranes and provide essential fatty acids, thereby preventing essential fatty acid deficiency. The two essential fatty acids are the omega-6 (n-6) polyunsaturated fatty acid (PUFA) linoleic acid (LA) and the omega-3 (n3) PUFA $\alpha$-linolenic acid (ALA). In the body these may be converted to longer chain, more unsaturated derivatives that have important biological functions [19]. LA is the metabolic precursor of arachidonic acid (ARA) while ALA is the metabolic precursor of eicosapentaenoic acid (EPA) and docosahexaenoic acid (DHA). The absence of lipids in artificial nutrition support regimens can result in the onset of essential fatty acid deficiency, especially in preterm infants, where there is insufficient synthesis of the omega- 3 fatty acid DHA and the omega- 6 fatty acid ARA from their essential precursors [20]. Lipids also allow for delivery of fat soluble vitamins.

Lipids used in nutrition support contain fats primarily in the form of triglycerides, with either medium-chain fatty acids (caprylic, capric, lauric and myristic acids), long-chain fatty acids (palmitic, oleic, linoleic and $\alpha$-linolenic acids) or very long chain fatty acids (EPA and DHA) [19]. Table 2 details the nomenclature and sources of fatty acids commonly used as a component of nutrition support. Triglycerides rich in medium-chain fatty acids have been

Table 1

Macronutrient composition of EN formulas commonly used in research studies.

\begin{tabular}{|c|c|c|c|c|c|}
\hline & Oxepa $^{1}$ & Pulmocare $^{1}$ & Ensure Plus $\mathrm{HN}^{2}$ & Impact $^{3}$ & Reconvan $^{4}$ \\
\hline Protein $(\mathrm{g} / \mathrm{l})$ & 63 & 63 & 63 & 56 & 55 \\
\hline Carbohydrate (g/l) & 105 & 105 & 204 & 132 & 120 \\
\hline \multirow[t]{2}{*}{ Fat $(g / l)$} & 93 & 93 & 49 & 28 & 33 \\
\hline & $\begin{array}{l}\text { (MCT, canola oil, } \\
\text { fish oil, borage oil) }\end{array}$ & $\begin{array}{l}\text { (MCT, canola oil, corn oil, } \\
\text { high oleic safflower oil) }\end{array}$ & $\begin{array}{l}\text { (MCT, canola } \\
\text { oil, corn oil) }\end{array}$ & $\begin{array}{l}\text { (Palm kernel oil, high oleic } \\
\text { sunflower oil, high oleic } \\
\text { safflower oil, fish oil) }\end{array}$ & $\begin{array}{l}\text { (MCT, safflower oil, } \\
\text { flaxseed oil, fish oil) }\end{array}$ \\
\hline Omega-6 PUFAs (g/l) & 18.4 & 18.4 & 7.7 & 5.8 & 6.9 \\
\hline Of which GLA ( $\mathrm{g} / \mathrm{l})$ & 4.3 & 0 & 0 & 0 & 0 \\
\hline Omega-3 PUFAs (g/l) & 10 & 4.8 & 1.5 & 3.3 & 3.4 \\
\hline Of which EPA + DHA (g/l) & 6.5 & 0 & 0 & 1.7 & 2.5 \\
\hline Also contains & $\begin{array}{l}\text { Taurine, carnitine, } \\
\text { vitamin } C, \alpha \text {-tocopherol, } \\
\beta \text {-carotene }\end{array}$ & $\begin{array}{l}\text { Taurine, carnitine, vitamin C, } \\
\alpha \text {-tocopherol, } \beta \text {-carotene }\end{array}$ & $\begin{array}{l}\text { Vitamin C, } \\
\alpha \text {-tocopherol }\end{array}$ & $\begin{array}{l}\text { Arginine, nucleotides, vitamin C, } \\
\alpha \text {-tocopherol, } \beta \text {-carotene }\end{array}$ & $\begin{array}{l}\text { Arginine, glutamine, } \\
\text { vitamin } C, \alpha \text {-tocopherol, } \\
\beta \text {-carotene }\end{array}$ \\
\hline
\end{tabular}

Source: ${ }^{1}$ Abbott Nutrition company website; ${ }^{2}$ Taken from [68]; ${ }^{3}$ Taken from [202] and Nestlé Health Science company website; ${ }^{4}$ Fresenius Kabi company website. 
Table 2

Fatty acids of importance in parenteral nutrition.

\begin{tabular}{lll}
\hline Fatty acid & $\begin{array}{l}\text { Shorthand } \\
\text { nomenclature }\end{array}$ & Oil source \\
\hline Caprylic acid & $8: 0$ & Coconut oil or palm kernel oil \\
Capric acid & $10: 0$ & Coconut oil or palm kernel oil \\
Lauric acid & $12: 0$ & Coconut oil or palm kernel oil \\
Myristic acid & $14: 0$ & \\
Palmitic acid & $16: 0$ & \\
Oleic acid & $18: 1 n-9$ & Olive oil \\
Linoleic acid & $18: 2 n-6$ & Vegetable seed oils e.g. soybean oil \\
$\alpha$-Linolenic acid & $18: 3 n-3$ & Vegetable seed oils e.g. soybean oil \\
Eicosapentaenoic acid & $20: 5 n-3$ & Fish oil \\
Docosahexaenoic acid & $22: 6 n-3$ & Fish oil \\
\hline
\end{tabular}

termed medium-chain triglycerides or MCTs. Soybean oil (SO) which is rich in linoleic acid, has been termed long-chain triglycerides or LCTs, although strictly speaking any triglyceride composed of long-chain fatty acids is a LCT. Fatty acid chain length, and the presence, number and position of double bonds affect physical, physiological and functional properties of the fatty acid [19]. Hence, different fatty acids can influence, in different ways, a number of different physiological processes such as metabolism, inflammation, immune response, oxidative stress, blood coagulation, organ function and wound healing [19].

The blend of lipids used in nutrition support has evolved over time. This is well illustrated by considering the lipid emulsions (LEs) used in PN (Fig. 1). The first generation of such LEs consisted purely of SO, with the second generation LEs including MCTs and the third generation beginning with the inclusion of structured lipids and olive oil (OO). Most recently third generation LEs containing fish oil (FO) have been introduced. Current commercially available LEs used in PN are detailed in Table 3 and include: pure SO; a 50:50 mixture of SO and MCTs (SO/MCT); inter-esterified SO and MCTs; a 20:80 mixture of soybean and olive oils (SO/OO; this is referred to herein as olive oil-based); a 40:50:10 mixture of SO, MCTs and FO (SO/MCT/FO); a 30:30:25:15 mixture of SO, MCTs, olive oil and FO (SO/MCT/OO/FO); and pure FO [21]. Additional components of lipid PN formulations include varying amounts of phytosterols (cholesterol-like structures that are present in plant oils); $\alpha$-tocopherol and other fat-soluble bioactives, depending on the fat source; and phospholipids, usually phosphatidylcholine (sometimes called lecithin), as an emulsifier.

The major physiological effects of the key fatty acids found in different lipids are summarized elsewhere $[19,22,23]$. SO is a source of the essential omega- 6 PUFA LA, which comprises about $50 \%$ of the fatty acids present and is the metabolic precursor of ARA. SO also contains some ( $7 \%$ of fatty acids) of the essential omega- 3 PUFA ALA. Because it is a precursor of ARA, an excess of LA is considered to promote inflammation, immunosuppression,

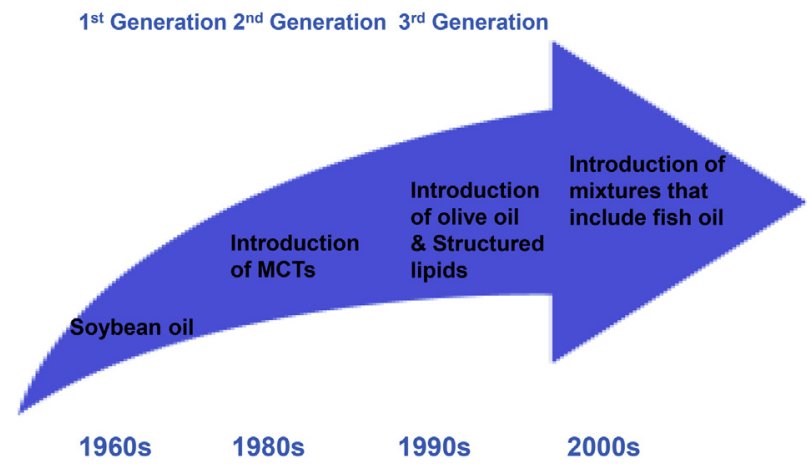

Fig. 1. Evolution of lipid emulsions for use in parenteral nutrition. coagulation, and fatty liver (hepatic steatosis) [24], although conclusive evidence for this is lacking. However, it is clear that high amounts of LA do impair synthesis of the omega-3 PUFAs EPA and DHA [25].

MCTs, a source of medium-chain saturated fatty acids usually from coconut oil, are a good energy source whilst not affecting blood triglyceride levels. They are ketogenic and protein sparing, and are relatively resistant to peroxidation [26,27]. MCTs do not appear to impair liver, immune or lung function [26,27]. However, rapid infusion of such a lipid emulsion in patients suffering from acute respiratory distress syndrome resulted in a deterioration of lung function and hemodynamics [28].

$\mathrm{OO}$, a source of oleic acid, is relatively neutral in its physiological effects, for example on immune function, inflammation and blood coagulation [29]. Because of its high content of monounsaturated fatty acids, $\mathrm{OO}$ is more resistant to peroxidation and oxidative stress than SO. Importantly, OO also preserves hepatobiliary function [30].

FO, a good source of EPA and DHA, is anti-inflammatory and may promote immune function and improve hepatic metabolism and liver function, including reversal of intestinal failure-induced fatty liver and cholestasis [19,23,31]. EPA and DHA also have anticoagulation and anti-arrhythmic effects, and oppose the actions of omega-6 PUFAs $[19,23]$. However, being very long chain, highly unsaturated fatty acids, both EPA and DHA are prone to peroxidation.

Lipids provided in EN are subject to the normal intestinal processes of digestion and absorption, with the products appearing in the bloodstream as triglyceride components of chylomicrons. LEs in PN bypass intestinal processes and so may be metabolized differently from lipoproteins originating from the gut. Once infused, the LEs, comprising triglycerides stabilized with a shell of phospholipids, acquire endogenous apoproteins that enable binding to and activation of lipoprotein lipase [32]. The structure of LEs (i.e., their fatty acid composition) appears to affect their rate of plasma clearance and hence tissue uptake. Animal studies have demonstrated that synthetic triglycerides comprising two medium chain and one long chain fatty acid clear faster than either MCTs or LCTs alone [33,34], an effect which is also observed in humans [35]. The addition of FO to an SO/MCT emulsion (SO:MCT:FO 40:50:10) resulted in faster plasma clearance than SO/MCT in both mice and humans [36,37].

The hydrolysis of circulating triglycerides arising from either enteral or parenteral lipid, yields free fatty acids that may enter adjacent tissues or remain in the circulation. The essential omega-3 PUFA ALA is not well incorporated into membrane phospholipids. However, the essential omega-6 PUFA LA, its metabolite ARA, and the metabolites of ALA EPA and DHA are incorporated into cell membrane phospholipids and into membrane lipid raft regions, thereby affecting the structure and function of membrane-bound proteins $[19,21]$. Thus these different PUFAs play a key role in cell membrane structure and function, regulation of gene expression and cell signaling pathways involved in apoptosis, metabolism, inflammation, cell-mediated immunity, blood clotting and organ function as well as synthesis of bioactive lipid mediators such as eicosanoids and docosanoids [19,21,22]. Eicosanoids are signaling molecules synthesized from 20-carbon PUFAs and include the prostaglandins (PGs), thromoboxanes (TXs) and leukotrienes (LTs) produced from ARA and EPA. Lipoxins produced from ARA and resolvins produced from EPA are also eicosanoids. Docosanoids are signaling molecules synthesized from 22-carbon PUFAs and include the resolvins, protectins and maresins produced from DHA.

Once incorporated into cell membranes, the metabolism of omega-6 and omega-3 PUFAs results in the production of eicosanoids and docosanoids that have differing roles in inflammation and immune response, platelet aggregation smooth-muscle 
Table 3

Oil and typical fatty acid compositions (\% of total) of commercially available lipid emulsions for use in parenteral nutrition.

\begin{tabular}{|c|c|c|c|c|c|c|c|}
\hline & Intralipid $^{\circledR}$ & $\begin{array}{l}\text { Lipofundin }^{\circledR} \\
\text { MCT/LCT }\end{array}$ & Structolipid $^{\circledR}$ & Omegaven ${ }^{\circledR}$ & ClinOleic $^{\circledR}$ & $\begin{array}{l}\text { Lipoplus }^{\circledR} \\
\text { (also known as Lipidem }^{\circledR} \text { ) }\end{array}$ & SMOFlipid $^{\circledR}$ \\
\hline Oil source & $\begin{array}{l}100 \% \\
\text { soybean }\end{array}$ & $\begin{array}{l}50 \% \mathrm{MCT}+50 \% \\
\text { soybean }\end{array}$ & $\begin{array}{l}36 \% \mathrm{MCT}+64 \% \\
\text { soybean }\end{array}$ & $100 \%$ fish $^{c}$ & $\begin{array}{l}80 \% \text { olive }+20 \% \\
\text { soybean }\end{array}$ & $\begin{array}{l}50 \% \text { MCT }+40 \% \\
\text { soybean }+10 \% \text { fish }^{c}\end{array}$ & $\begin{array}{l}30 \% \mathrm{MCT}+30 \% \\
\text { soybean }+25 \% \\
\text { olive }+15 \% \text { fish }\end{array}$ \\
\hline SFA & 15 & 58 & 46 & 21 & 14 & 49 & 37 \\
\hline MUFA $^{\mathrm{a}}$ & 24 & 11 & 14 & 23 & 64 & 14 & 33 \\
\hline PUFA & 61 & 31 & 40 & 56 & 22 & 37 & 30 \\
\hline n-3 PUFA & 8 & 4 & 5 & 48 & 3 & 10 & 7 \\
\hline ALA & 8 & 4 & 5 & 1 & 3 & 4 & 2 \\
\hline EPA & - & - & - & 20 & - & 3.5 & 3 \\
\hline DHA & - & - & - & 19 & - & 2.5 & 2 \\
\hline n-6 PUFA ${ }^{b}$ & 53 & 27 & 35 & 5 & 19 & 27 & 23 \\
\hline
\end{tabular}

Information taken from [203-205].

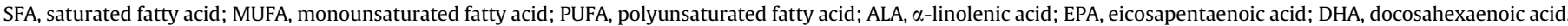

a Mainly oleic acid.

b Mainly linoleic acid.

c The fatty acid composition of fish oil is more variable than that of vegetable oils so that the precise contribution of different fatty acids may differ in different batches.

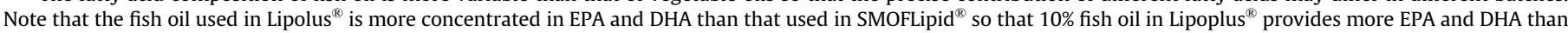
$15 \%$ fish oil in SMOFLipid ${ }^{\circledR}$.

contraction and so on [19]. The omega-6 PUFA ARA is metabolized to pro-inflammatory lipid mediators such as the 2-series PGs and TXs and the 4-series LTs [38,39]. It also gives rise to antiinflammatory and inflammation resolving lipoxins [40]. Preclinical studies have highlighted the importance of lipid mediators produced from ARA in sepsis. Direct inhibition of cyclooxygenase-2 and 5-lipoxygenase, enzymes involved in the synthesis of ARAderived pro-inflammatory mediators (PGs, TXs, LTs), results in increased lipoxins which attenuate the inflammatory response and protect from sepsis [41]. Furthermore, administration of ARAderived lipoxin $\mathrm{A}_{4}$ in a mouse model of sepsis increased survival through reduction of systemic inflammation and blood bacterial load [42]. The omega-3 PUFAs EPA and DHA compete with ARA and result in synthesis of weaker pro-inflammatory 3-series PGs and TXs and 5-series LTs [43]. EPA and DHA also give rise to resolvins (both EPA and DHA), protectins and maresins (DHA only), which play a key role in resolution of inflammation, reduction of tissue injury and promotion of wound healing [44]. Resolvins reduce the inflammatory response via decreasing neutrophil invasion, reduction of synthesis of pro-inflammatory cytokines via inhibition of $\mathrm{NF}-\mathrm{kB}$, recruitment of monocytes, increased phagocytosis of apoptotic neutrophils and facilitation of removal of macrophages via the lymphatic system $[44,45]$. Rodent models have demonstrated that the inflammation-resolving effect of DHA-derived resolvin D2 is associated with increased survival in bacterial sepsis [46]. Resolvin D2 was able to decrease local and systemic bacterial burden, excessive cytokine production and neutrophil recruitment, whilst increasing macrophage phagocytosis [46]. EPA and DHA also exert an anti-inflammatory effect acting through other mechanistic pathways, including suppression of nuclear factor kappa B signaling via activation of the cell surface GPR120 protein and the intracellular receptor peroxisome proliferator activated receptor $\gamma$, and thus inhibition of production of a range of pro-inflammatory cytokines, adhesion molecules, cyclooxygenase2 , inducible nitric oxide synthase and matrix metalloproteinases $[19,43]$.

It is evident from the forgoing discussion that individual fatty acids have unique functional properties and that different members of the same fatty acid family (saturated, omega-6, omega-3) do not share the same properties [19]. For this reason, it is important that discussion of the role of the fatty acid composition of lipids to be used in nutritional support of patients in the ICU (or elsewhere) should focus on individual fatty acids rather than on fatty acid families. Therefore, discussion of compositional properties such as the omega- 6 to omega- 3 ratio is not valuable. This is because this ratio can be altered in many different ways that may not have the same functional or clinical impact. For example, the omega-3 fatty acid component may be altered by using more ALA or by using more EPA + DHA and the outcome from those two scenarios is likely to be different. This is discussed further elsewhere $[47,48]$.

\section{Fish oil-enriched EN in critically ill patients}

ESPEN guidelines state that an immune-modulating EN formula enriched with arginine, nucleotides and omega- 3 fatty acids is superior to standard enteral formula in certain groups of patients, i.e. upper gastrointestinal surgical patients, trauma patients and patients with mild sepsis [3]. No benefit has been established in patients with severe sepsis, in whom an immune-modulating formula may be harmful and is therefore not recommended [3]. ASPEN and SCCM have previously issued similar guidelines [4], but these have been modified recently and suggest that immunemodulating enteral formulations (containing arginine with other agents, including omega- 3 fatty acids, glutamine and nucleic acids) should not be used routinely in the medical ICU [49]. Consideration for these formulations should be reserved for patients with traumatic brain injury and perioperative patients in the surgical ICU [49].

Regarding critically ill patients with acute respiratory distress syndrome (ARDS) and severe acute lung injury (ALI), ESPEN guidelines state that such patients should receive an enteral formulation characterized by an anti-inflammatory lipid profile (i.e. omega-3 rich FO, borage oil) and antioxidants [3], a guideline previously supported by ASPEN and SCCM [4]. However, in 2013, the Canadian Clinical Practice Guidelines reviewed new study data investigating the effect of such EN formulas in critically ill patients with ALI/ARDS and downgraded the recommendation to "should be considered" from "recommended" due to a diminished effect on mortality risk [50]. Furthermore, ASPEN in 2016 decided not to make any recommendation in this area [49]. Details of the studies discussed in the following sections may be found in Table 4.

\subsection{ALI/ARDS}

ARDS is characterized by diffuse pulmonary inflammation, increased vascular permeability and edema [51,52]. Whilst a 
Table 4

Clinically relevant outcomes of studies using fish oil-enriched EN in critically ill patients.

\begin{tabular}{|c|c|c|c|c|c|c|c|}
\hline Study & $\begin{array}{l}\text { Population } \\
\text { (Number } \\
\text { enrolled/included } \\
\text { in analysis) }\end{array}$ & Intervention & $\begin{array}{l}\text { EPA } \\
(g / d)\end{array}$ & $\begin{array}{l}\text { DHA } \\
(\mathrm{g} / \mathrm{d})\end{array}$ & $\begin{array}{l}\text { GLA } \\
(\mathrm{g} / \mathrm{d})\end{array}$ & Control & Outcome in intervention group \\
\hline Braga et al. 2002 [69] & $\begin{array}{l}\text { Major abdominal } \\
\text { surgery for GI } \\
\text { malignancy } \\
(196 / 150)\end{array}$ & $\begin{array}{l}\text { Peri- \& post-operative } \\
\text { IMPACT }^{\circledR}\end{array}$ & \multicolumn{2}{|c|}{$\sim 2.9 \mathrm{EPA}+\mathrm{DHA}$} & 0 & $\begin{array}{l}\text { Post-operative } \\
\text { standard EN }\end{array}$ & $\begin{array}{l}\downarrow \text { Number of complications } \\
\downarrow \text { Hospital length of stay }\end{array}$ \\
\hline Elamin et al. 2012 [59] & $\begin{array}{l}\text { ARDS } \\
(22 / 17)\end{array}$ & Oxepa $^{\circledR}$ & $\mathrm{N} / \mathrm{A}$ & $\mathrm{N} / \mathrm{A}$ & $\mathrm{N} / \mathrm{A}$ & Pulmocare $\left.^{(}\right)$ & $\begin{array}{l}\uparrow \text { Oxygenation } \\
\downarrow \text { Lung injury } \\
\downarrow \text { Organ dysfunction } \\
\downarrow \text { ICU stay }\end{array}$ \\
\hline Gadek et al. 1999 [56] & $\begin{array}{l}\text { ARDS } \\
(146 / 98)\end{array}$ & Oxepa $^{\circledR}$ & 6.9 & 2.9 & 5.8 & Pulmocare $^{\circledR}$ & $\begin{array}{l}\uparrow \text { Oxygenation } \\
\downarrow \text { Ventilator days } \\
\downarrow \text { New organ failure } \\
\downarrow \text { ICU stay }\end{array}$ \\
\hline Grau-Carmona et al. 2011 [60] & $\begin{array}{l}\text { Septic patients } \\
\text { with ALI/ARDS } \\
(160 / 132)\end{array}$ & Oxepa $^{\circledR}$ & 5.4 & 2.3 & 4.9 & Ensure Plus HN ${ }^{\circledR}$ & $\begin{array}{l}\uparrow \text { Oxygenation } \\
\downarrow \text { New organ failure } \\
\downarrow \text { ICU stay }\end{array}$ \\
\hline Kagan et al. 2015 [71] & $\begin{array}{l}\text { Severe trauma } \\
(120 / 99)\end{array}$ & Oxepa ${ }^{\circledR}$ & 5.5 & 2.3 & 4.7 & Pulmocare $^{\circledR}$ & $\begin{array}{l}\text { No effect on oxygenation, } \\
\text { incidence of ARDS/ALI, length } \\
\text { of ventilation time, length of ICU } \\
\text { stay or } 28 \text {-day mortality }\end{array}$ \\
\hline Klek et al. 2011 [70] & $\begin{array}{l}\text { Major abdominal } \\
\text { surgery for GI } \\
\text { malignancy } \\
(341 / 305)\end{array}$ & $\begin{array}{l}\text { Post-operative } \\
\text { Reconvan }^{\circledR}\end{array}$ & $\sim 5 \mathrm{EPA}$ & DHA & 0 & $\begin{array}{l}\text { Post-operative } \\
\text { Peptisorb }^{\circledR}\end{array}$ & $\begin{array}{l}\downarrow \text { Hospital stay } \\
\downarrow \text { Infectious complications } \\
\downarrow \text { Overall morbidity } \\
\downarrow \text { Overall mortality }\end{array}$ \\
\hline Pontes-Arruda et al. 2006 [58] & $\begin{array}{l}\text { ARDS secondary } \\
\text { to sepsis/septic shock } \\
(165 / 103)\end{array}$ & Oxepa $^{(}$ & 4.9 & 2.2 & 4.6 & Pulmocare $^{\circledR}$ & $\begin{array}{l}\uparrow \text { Oxygenation } \\
\downarrow \text { New organ failure } \\
\downarrow \text { Ventilator days } \\
\downarrow \text { ICU stay } \\
\downarrow \text { Mortality }\end{array}$ \\
\hline Pontes-Arruda et al. 2011 [68] & $\begin{array}{l}\text { Early stage } \\
\text { sepsis } \\
(115 / 106)\end{array}$ & Oxepa ${ }^{\circledR}$ & 4.6 & 2.0 & 4.4 & Ensure Plus $\mathrm{HN}^{\circledR}$ & $\begin{array}{l}\downarrow \text { Progression of sepsis } \\
\downarrow \text { Respiratory and cardiac failure } \\
\downarrow \text { ICU stay }\end{array}$ \\
\hline Rice et al. 2011 [61] & $\begin{array}{l}\text { ARDS/ALI } \\
(272 / 272)\end{array}$ & Bolus FO + GLA & 6.8 & 3.4 & 5.9 & $\begin{array}{l}\text { Equivalent with } \\
\text { no FO or GLA }\end{array}$ & $\begin{array}{l}\text { No clinical benefit. Trial stopped } \\
\text { early due to fewer ventilator-free } \\
\text { and ICU-free days, and greater } \\
60 \text {-day mortality in FO group }\end{array}$ \\
\hline Singer et al. 2006 [57] & $\begin{array}{l}\text { ALI } \\
(100 / 95)\end{array}$ & Oxepa $^{\circledR}$ & 5.4 & 2.5 & 5.1 & Pulmocare $^{\circledR}$ & $\begin{array}{l}\uparrow \text { Oxygenation } \\
\downarrow \text { Ventilator duration }\end{array}$ \\
\hline Stapleton et al. 2011 [62] & $\begin{array}{l}\text { ALI } \\
(90 / 85)\end{array}$ & Bolus FO & 9.8 & 6.8 & 0 & $\begin{array}{l}\text { Equivalent with } \\
\text { no FO }\end{array}$ & $\begin{array}{l}\text { No effect on SOFA, ventilator } \\
\text { free days or mortality }\end{array}$ \\
\hline Van Zanten et al. 2014 [73] & $\begin{array}{l}\text { Medical/surgical/ } \\
\text { trauma ICU patients } \\
(301 / 301)\end{array}$ & $\begin{array}{l}\text { Experimental high } \\
\text { protein feed enriched } \\
\text { with glutamine, } \\
\text { omega-3 fatty acids \& } \\
\text { antioxidants }\end{array}$ & $\sim 4.5 \mathrm{EP}$ & + DHA & 0 & $\begin{array}{l}\text { Protison } \\
\text { (high protein } \\
\text { feed) }\end{array}$ & $\begin{array}{l}\text { No effect on infections, mortality, } \\
\text { organ failure, duration of mechanical } \\
\text { ventilation or length of stay. } \\
\text { Increased } 6 \text {-month mortality rate } \\
\text { reported in medical sub-group. }\end{array}$ \\
\hline
\end{tabular}

SOFA, Sequential Organ Failure Assessment score.

previous definition separated ALI from ARDS as a non-severe form (old definition [53]) and the term is still used in preclinical models, ALI is now defined as mild ARDS (Berlin Definition). Evidence from preclinical models of ALI/ARDS suggests that nutritional supplementation of EN with omega-3 fatty acids may improve vascular leakage, pulmonary inflammation and gas exchange and oxygenation [54,55].

Several clinical studies in patients with ALI/ARDS have shown that continuously-administered EN enriched with EPA, DHA, $\gamma$ linolenic acid (GLA, an omega- 6 fatty acid present in borage oil) and anti-oxidants, resulted in improved oxygenation [56-59] and reduced duration of ventilation [56-58], decreased new organ failure [56,58,59] and shortened ICU stay [56,58-60] compared with standard EN. There is little evidence supporting the use of this formulation in mortality reduction in this patient population, apart from one study in patients with ARDS secondary to sepsis [58].

In contrast to these positive findings, two studies that utilized bolus administration of enteral FO in patients with ALI, found no clinical benefit compared with standard EN [61,62], with one trial being stopped early due to futility and reporting fewer ventilator- and ICU-free days, and a non-significant increase in the 60-day mortality in the FO group [61]. Compared to continuous administration, bolus delivery may not enable sufficient incorporation of EPA and DHA into cell membranes, which may have played a role in these negative findings. Furthermore, in one trial, whilst underfeeding occurred in both intervention and control groups, a fivefold higher protein intake was reported in the control group, which is likely also to have contributed to the lack of effect seen in the study group [61,63].

A meta-analysis of 955 patients with ARDS/ALI concluded that FO-enriched EN had no effect on 28-day mortality [64]. However, a sensitivity analysis demonstrated that, on exclusion of the two studies delivering a bolus of FO, there is evidence that supports the use of continuous administration of EN containing FO in decreasing mortality in critically ill patients, including patients with ALI/ARDS [65]. However, ASPEN decided to make no recommendation at this time regarding the routine use of an enteral formulation characterized by an anti-inflammatory lipid profile (i.e. omega-3 rich FO, borage oil and antioxidants) in patients with ARDS and severe ALI, given the conflicting data [49]. 


\subsection{Sepsis}

Sepsis is associated with a hyper-inflammatory response which directly and indirectly causes widespread tissue damage, through the release of pro-inflammatory mediators, proteases and oxidants from activated macrophages, as well as vasodilators such as nitric oxide, which acts as a key mediator in septic shock [66,67].

Whilst no definitive study demonstrates that the use of EN enriched with omega-3 fatty acids results in improved outcomes for critically ill patients with sepsis, there does appear to be clinical benefit when administered in early-stage sepsis. Specifically, in patients without any sepsis-associated organ failure, administration of FO-enriched EN resulted in reduction in the progression of sepsis as well as in respiratory and cardiac failure and a reduced length of ICU stay compared with a lower lipid-containing EN [68].

\subsection{Major abdominal surgery}

There is evidence supporting the use of FO-enriched EN in major abdominal surgery. Peri-operative administration of EN containing arginine, omega-3 fatty acids and RNA was reported to reduce postoperative complications and hospital length of stay in malnourished cancer patients undergoing major abdominal surgery versus standard post-operative EN [69]. Furthermore, immunemodulating EN (containing omega-3 fatty acids, arginine and glutamine) administered post-operatively to malnourished patients undergoing resection for pancreatic/gastric cancer resulted in a shorter hospital stay, fewer infectious complications and reduced morbidity and mortality compared to post-operative standard oligopeptide EN [70].

\subsection{Severe trauma}

There are few studies assessing the effect of FO-enriched EN specifically on trauma patients. One study administered preemptively FO-enriched EN (containing EPA, DHA, GLA and antioxidants) to severe trauma patients to assess its effect on the development of respiratory complications, but found no difference in the level of oxygenation $\left(\mathrm{PaO}_{2} / \mathrm{FiO}_{2}\right.$ ratio), incidence of ARDS/ALI, duration of ventilation, length of ICU stay or 28-day mortality compared with a high fat/low carbohydrate EN formulation [71]. However, whilst red blood cell EPA, GLA and omega-3 index (the sum of EPA plus DHA) increased significantly in the study group, the optimal omega-3 index required for clinical efficacy failed to be reached, and this may have contributed to the study's negative findings. This raises the importance of omega- 3 fatty acid baseline measurement in ICU patients, to determine the extent of incorporation during supplementation; ultimately such measurements could be used as a predictor of therapeutic efficacy [72].

\subsection{Benefit versus harm of immune-modulating EN in ICU patients}

The ESPEN guidelines recommend the use of FO-enriched EN in subgroups of critically ill patients and there are a number of studies (discussed above) that show clinical benefit of such EN. However, a recent study has raised questions concerning the benefit and harm of immune-modulating EN. Van Zanten et al. conducted a multicenter trial in 301 mechanically ventilated critically ill patients, and found that high protein EN enriched with immune-modulating nutrients (glutamine, omega-3 PUFAs, selenium and antioxidants) had no effect on infections and other clinical endpoints (mortality, organ failure, duration of mechanical ventilation, length of stay) compared with standard high protein EN [73]. The study population comprised medical, surgical and trauma ICU patients. Sub-group analysis found that medical ICU patients had increased 6-month mortality rates in the enriched EN group suggesting that in this particular medical population, immune modulating EN should not be used. Specifically, these results, together with the increased mortality observed in the REDOXS trial [74] raise concerns over the safety of the glutamine component of the enteral feed in certain ICU patients.

\section{Clinical and biochemical effects of different lipid emulsions in PN used in critically ill patients}

ESPEN guidelines recommend that lipids should be an essential part of PN for energy and to ensure essential fatty acid provision, and that intravenous LEs can be administered safely at a rate of $0.7 \mathrm{~g} / \mathrm{kg}$ up to $1.5 \mathrm{~g} / \mathrm{kg}$ over $12-24 \mathrm{~h}$ [13]. However, the choice of lipid used in PN may have an effect on clinical outcomes in the critically ill patient.

\subsection{Soybean oil-based lipid emulsions}

As discussed in Section 2, pure SO may have a number of less desirable effects on physiological processes, such as promoting inflammation and suppressing immune function due to its high LA content, and a tendency for peroxidation due to its relatively low $\alpha$ tocopherol content. Pure SO has also been associated with a number of complications including hyperbilirubinemia and intestinal failure associated liver disease (IFALD). SO intake may increase the lung flow of lymph and pulmonary pressure, and decrease the partial pressure of oxygen in arterial blood $\left(\mathrm{PaO}_{2}\right)$ resulting in respiratory acidosis, and modify lipid metabolism when compared to second and third generation lipids [75,76].

There is evidence that SO-based PN might exacerbate the postsurgical inflammatory response in gastrointestinal surgery patients with severe surgical-related stress, and impair immune function when compared to standard glucose-containing PN [77]. The proinflammatory effect of the SO emulsion was not so pronounced in patients with moderate surgery-related stress. An immunosuppressive effect was also seen in polytrauma patients receiving early SO-containing $\mathrm{PN}$, which was associated with higher rates of infection, reduced $\mathrm{T}$ cell function and lowered natural killer cell activity [78]. This was linked to longer duration of mechanical ventilation and longer ICU and hospital stay, compared to standard glucose-containing PN [78]. However, neither of these studies examined the impact of other lipids to which the effects of SO could be compared.

The accumulating evidence base has resulted in a recommendation from the German Society for Nutritional Medicine (DGEM) that pure SO LEs should no longer be used in PN support of critically ill patients [79]. DGEM will further refine its recommendation in its updated guidelines and will advise that ICU patients should receive second or third generation LEs with reduced content of omega- 6 fatty acids (M. Adolph and K. Mayer, personal communication; [80]). ASPEN suggest withholding SO-based LEs during the first week following initiation of PN in the critically ill patient or limiting this to a maximum of $100 \mathrm{~g} / \mathrm{wk}$ (often divided into 2 doses/wk) if there is concern about essential fatty acid deficiency [49].

\subsection{Olive oil-based lipid emulsions}

OO-based LEs appear to be a safe alternative to pure SO-based LEs, which is reflected in the ESPEN guidance that OO-based PN is well tolerated in critically ill patients [13]. Using OO-based PN in adult surgical patients results in better fatty acid status, increased blood vitamin E concentration, decreased lipid peroxidation and decreased inflammatory variables [81-83]. However, the evidence 
base for the potential for OO-based LEs to improve clinical outcomes is not consistent. In surgical ICU patients administered OO-based PN for up to 28 days post-surgery, there was no difference in glycemic control, immune function, or inflammatory or oxidative stress markers compared to SO-based PN [84]. Mortality rate, incidence of nosocomial infections and acute renal failure, as well as length of stay, were all reported to be similar between the two groups. Mateude Antonio et al. also found no difference in the number or type of infections, length of ICU or hospital stay or mortality following an average duration of 19 days of post-operative OO-based PN compared to SO in surgical ICU patients [85].

\subsection{SO/MCT-based lipid emulsions}

There is good evidence that supports the use of SO/MCT LEs instead of pure SO in critically ill patients. A study in severely malnourished surgical patients receiving peri-operative total PN reported a significantly lower incidence of intra-abdominal abscesses with SO/MCT versus SO [86]. There was no reported difference in other infection rates or mortality. SO/MCT is also associated with a shorter period of mechanical ventilation in critically ill patients with COPD compared to SO [87].

\subsection{Fish oil-containing lipid emulsions}

ESPEN guidelines state that addition of EPA and DHA to LEs has demonstrable effects on cell membranes and inflammatory processes, and that FO-enriched lipid emulsions probably decrease length of stay in critically ill patients [13]. DGEM will also state that specific LEs enriched with omega-3 fatty acids may be considered for administration in critically ill patients (M. Adolph and K. Mayer, personal communication). There have been a number of studies investigating the effect of FO-enriched PN in critically ill patients (see Tables 5-7 for more details about the studies included in the following sections).

\subsubsection{Fish oil-enriched $P N$ in surgical ICU patients}

Administration of FO-enriched $\mathrm{PN}$ in patients undergoing major surgical procedures appears to be effective in lowering the postoperative inflammatory response. For example, suppression of the pro-inflammatory cytokine IL-6 was reported following parenteral FO administration in elderly patients undergoing hip surgery compared to the absence of intravenous FO administration [88]. Furthermore, perioperative infusion of FO in cardiac surgery patients significantly increased platelet EPA and DHA and atrial tissue EPA together with a decrease in IL-6 concentrations, with no adverse effects reported compared with the saline control [89]. Compared to SO, perioperative FO-enriched PN in surgical ICU patients decreased post-operative serum IL- 6 and whole blood tumor necrosis factor (TNF)- $\alpha$ production, and increased monocyte expression of human leukocyte antigen-DR (a marker of immune competence) [90]. This effect was associated with a shorter hospital stay in the FO-enriched PN group, but there was no difference in infection rate or mortality. Administration of FO-enriched PN $(\mathrm{FO}+\mathrm{SO})$ for $7 \mathrm{~d}$ post-gastrointestinal surgery resulted in significantly fewer incidences of systemic inflammatory response syndrome (SIRS) and significantly shorter hospital stay compared with So alone [91]. There was also a trend toward fewer infectious complications in the FO-enriched PN group. Similar results were reported for short-term ( $3 \mathrm{~d}$ ) pre-operative infusion of FO alone in gastrointestinal cancer patients awaiting surgery [92]. Administration of FO improved the post-operative immune response (decreased interleukin (IL)-6 and IL-10, decreased leukocyte oxidative burst, maintenance of monocyte percentage expressing human leukocyte antigen-DR and CD32, and increased neutrophil
CD32 expression) but had no effect on post-operative infections or length of ICU or hospital stay [92].

There is also evidence supporting the post-operative administration of FO-containing PN in gastric surgery patients in improving post-surgical immune competence, lowering infection rate and shortening hospital stay. In elderly patients following colorectal cancer surgery, administration of PN containing FO + SO for $7 \mathrm{~d}$ resulted in lowered levels of IL- 6 and TNF- $\alpha$ and fewer CD8 positive cells in the bloodstream, fewer infectious complications and incidences of SIRS, and shorter length of hospital stay compared with SO alone [93]. Furthermore, a study in gastric carcinoma patients undergoing major abdominal surgery reported that post-operative PN enriched with FO resulted in fewer infectious complications and a shorter hospital stay compared with standard PN [94]. A reduced infection rate was also found in gastrointestinal surgery patients following 5 days of post-operative PN containing OO/SO enriched with FO compared to OO/SO alone [95], whilst another study found a shorter length of hospital stay was associated with FO-enriched SO/MCT compared to SO alone in gastrointestinal surgery patients [96]. Decreased length of hospital stay was found to be associated with 5 days of post-operative administration of SO/MCT/OO/FOcontaining PN compared to SO-based PN in gastrointestinal surgery patients [97]. Furthermore, in liver transplantation patients, FO-enriched PN given for 7 days post-surgery resulted in a decreased length of hospital stay compared to SO/MCT [98]. Perioperative administration of FO-enriched PN in surgical patients appears to have a beneficial effect on clinical outcomes as suggested by Heidt et al. from a study in coronary artery bypass graft patients which resulted in a shortened ICU stay compared to SObased PN [99] and Tsekos et al.'s study in gastrointestinal surgery patients which resulted in decreased mortality, decreased requirement for mechanical ventilation and decreased hospital stay compared to SO/MCT-containing PN [100].

These findings are supported by a meta-analysis of 23 studies including 1502 surgical and ICU patients which investigated the effects of FO-enriched PN compared with other LEs (SO, SO/MCT, OO/SO) on various clinical outcomes [101]. Whilst the authors found no effect on mortality, FO-enriched PN resulted in a clinically and statistically significant reductions in infection rate and in length of ICU and hospital stay. A smaller meta-analysis of 7 RCTs also concluded that post-operative administration of FO-enriched $\mathrm{PN}$ in major abdominal surgery patients has a beneficial effect on post-operative infection rates and length of ICU and hospital stay [102]. Furthermore, a meta-analysis of five trials performed by Manzanares et al. found that FO administered either parenterally or enterally resulted in a non-statistically significant trend toward reduced duration of mechanical ventilation [103].

In addition to its positive effects on inflammation and immune function, FO-enriched PN may help to preserve liver function in critically ill surgical patients. Decreased total bilirubin as well as serum IL-6, TNF- $\alpha$ and nuclear factor kappa B was reported in gastrointestinal surgical patients following post-operative administration of FO-enriched PN compared with SO/MCT [104]. Rates of infectious complications and SIRS were comparable between the two groups. A similar study also utilizing FO-enriched PN versus $\mathrm{SO} / \mathrm{MCT}$ in post-operative patients, found similar results, although statistical significance was not reached for the reductions in liver dysfunction, infection rate and serum pro-inflammatory cytokines [105]. In comparison with pure SO, FO/SO (20:80) administered post-operatively to major abdominal surgery patients resulted in significantly decreased markers of liver dysfunction (ALT and AST), bilirubin and lipase [106]. Weight was maintained in the FOenriched PN group, as well as a tendency toward shorter ICU stay in those patients at risk of sepsis [106]. Hence FO-enriched PN improved liver and pancreas function in this patient population, 


\begin{tabular}{|c|c|c|c|c|c|}
\hline Study & Population & Intervention & Duration & Control & Outcome in intervention group \\
\hline Badía-Tahull et al. 2010 [95] & Gastrointestinal surgery & $\begin{array}{l}\text { OO/SO + FO }\left(\text { ClinOleic }^{\circledR}+\text { Omegaven }^{\circledR}\right) \\
(\mathrm{n}=13)\end{array}$ & $5 \mathrm{~d}$ & $\mathrm{OO} / \mathrm{SO}\left(\right.$ ClinOleic $\left.^{\sqrt{ }}\right)(\mathrm{n}=14)$ & $\begin{array}{l}\downarrow \text { Number of infections. } \\
\text { Trend toward lower mortality and fewer } \\
\text { incidences of sepsis. } \\
\text { No effect on length of hospital stay }\end{array}$ \\
\hline Berger et al. 2008 [206] & $\begin{array}{l}\text { Abdominal aorta } \\
\text { aneurysm surgery }\end{array}$ & SO/MCT/FO $\left(\right.$ Lipoplus $\left.^{\mathbb{1}}\right)(\mathrm{n}=12)$ & $4 \mathrm{~d}$ & $\begin{array}{l}\left.\text { SO/MCT (Lipofundin }{ }^{\circledR}\right) \\
(\mathrm{n}=12)\end{array}$ & Trend toward shorter ICU and hospital stay \\
\hline Berger et al. 2013 [89] & Cardiac surgery & FO $\left(\right.$ Omegaven $\left.^{\circledR}\right)(\mathrm{n}=14)$ & $\begin{array}{l}3 \text { infusions: } 12 \mathrm{~h} \text { and } 2 \mathrm{~h} \\
\text { before surgery and } \\
\text { immediately after surgery }\end{array}$ & Saline $(\mathrm{n}=14)$ & $\begin{array}{l}\text { Trend toward shorter length of mechanical } \\
\text { ventilation and shorter ICU stay }\end{array}$ \\
\hline Grimm et al. 2006 [97] & Gastrointestinal surgery & SO/MCT/OO/FO $\left(\right.$ SMOFlipid $\left.^{\circledR}\right)(\mathrm{n}=19)$ & $5 \mathrm{~d}$ & SO $\left(\right.$ Lipovenoes $\left.^{(\mathbb{R}}\right)(\mathrm{n}=14)$ & $\downarrow$ Length of hospital stay \\
\hline Han et al. 2012 [105] & Major surgery & $\begin{array}{l}\left.\text { SO/MCT + FO (Lipofundin }{ }^{\circledR}+\text { Omegaven }^{\circledR}\right) \\
(\mathrm{n}=18)\end{array}$ & $7 \mathrm{~d}$ post-surgery & $\begin{array}{l}\text { SO/MCT }\left(\text { Lipofundin }^{\circledR}\right) \\
(\mathrm{n}=12)\end{array}$ & $\begin{array}{l}\text { Trend toward less liver dysfunction and fewer } \\
\text { infections }\end{array}$ \\
\hline Heidt et al. 2009 [99] & $\begin{array}{l}\text { Coronary artery } \\
\text { bypass surgery }\end{array}$ & FO $\left(\right.$ Omegaven $\left.{ }^{\circledR}\right)(n=52)$ & $\begin{array}{l}\sim 12 \mathrm{~h} \text { prior to surgery } \\
\text { until ward transfer }\end{array}$ & $\begin{array}{l}\text { SO }\left(\text { Lipovenoes }^{\circledR}\right) \\
(\mathrm{n}=50)\end{array}$ & $\begin{array}{l}\downarrow \text { Post-operative atrial fibrillation } \\
\downarrow \text { ICU stay }\end{array}$ \\
\hline Heller et al. 2004 [106] & Gastrointestinal surgery & $\begin{array}{l}\text { SO }+ \text { FO }\left(\text { Lipovenoes }^{\circledR}+\text { Omegaven }^{\circledR}\right) \\
(\mathrm{n}=24)\end{array}$ & $5 \mathrm{~d}$ post-surgery & $\begin{array}{l}\text { SO }\left(\text { Lipovenoes }{ }^{\circledR}\right) \\
(\mathrm{n}=20)\end{array}$ & $\downarrow$ Markers of liver dysfunction \\
\hline Jiang et al. 2010 [91] & Gastrointestinal surgery & $\begin{array}{l}\text { SO }+ \text { FO }\left(\text { Intralipid }^{\circledR}+\text { Omegaven }^{\circledR}\right) \\
(\mathrm{n}=100)\end{array}$ & $7 \mathrm{~d}$ post-surgery & SO $\left(\right.$ Intralipid $\left.^{\circledR}\right)(\mathrm{n}=103)$ & $\begin{array}{l}\downarrow \text { SIRS } \\
\downarrow \text { Length of hospital stay } \\
\text { Trend toward fewer infectious complications. }\end{array}$ \\
\hline Klek et al. 2005 [94] & Gastrointestinal surgery & $\begin{array}{l}\text { Post-operative FO }\left(\text { Omegaven }^{\circledR}\right) \\
(\mathrm{n}=30)\end{array}$ & Mean duration $9 \mathrm{~d}$ & $\begin{array}{l}\text { SO/MCT }\left(\text { Lipofundin }^{\circledR}\right)(\mathrm{n}=30) \\
\text { SO/MCT }+ \text { glutamine } \\
\left(\text { Lipofundin }^{\circledR}+\text { Dipeptiven }^{\circledR}\right)(\mathrm{n}=30)\end{array}$ & $\begin{array}{l}\downarrow \text { Infectious complications } \\
\downarrow \text { Hospital stay }\end{array}$ \\
\hline Ma et al. 2012 [108] & Gastrointestinal surgery & $\begin{array}{l}\left.\text { SO/MCT/OO/FO (SMOFlipid }{ }^{\circledR}\right) \\
(\mathrm{n}=20)\end{array}$ & $5 \mathrm{~d}$ post-surgery & $\begin{array}{l}\text { SO/MCT }\left(\text { Lipovenoes }^{\mathbb{B}}\right) \\
(\mathrm{n}=20)\end{array}$ & $\begin{array}{l}\text { No difference in post-operative complications, } \\
\text { infections or duration of hospital stay }\end{array}$ \\
\hline $\begin{array}{l}\text { Mateu-de Antonio } \\
\text { et al. } 2008 \text { [85] }\end{array}$ & Surgery patients & $\mathrm{OO} / \mathrm{SO}\left(\mathrm{ClinOleic}^{\circledR}\right)(\mathrm{n}=23)$ & Mean duration $19 \mathrm{~d}$ & SO $\left(\right.$ Intralipid $\left.^{\circledR}\right)(n=16)$ & $\begin{array}{l}\text { No difference in number and type of infections, } \\
\text { ICU stay, hospital stay or mortality. }\end{array}$ \\
\hline Metry et al. 2014 [109] & Gastrointestinal surgery & SO/MCT/OO/FO $\left(\right.$ SMOFlipid $\left.^{\circledR}\right)(\mathrm{n}=41)$ & $7 \mathrm{~d}$ post-surgery & SO $\left(\right.$ Intralipid $\left.{ }^{\circledR}\right)(n=42)$ & $\begin{array}{l}\text { No difference in ventilation, duration of ICU or } \\
\text { hospital stay or mortality }\end{array}$ \\
\hline Piper et al. 2009 [107] & Surgery & SO/MCT/OO/FO $\left(\right.$ SMOFlipid $\left.^{\circledR}\right)(\mathrm{n}=22)$ & $5 \mathrm{~d}$ post-surgery & $\mathrm{OO} / \mathrm{SO}\left(\right.$ ClinOleic $\left.^{\circledR}\right)(\mathrm{n}=22)$ & $\downarrow$ Markers of liver dysfunction \\
\hline $\begin{array}{l}\text { de Miranda Torrinhas } \\
\text { et al. } 2013 \text { [92] }\end{array}$ & Gastrointestinal surgery & $\begin{array}{l}\text { Pre-operative FO }\left(\text { Omegaven }^{\circledR}\right) \\
(\mathrm{n}=31)\end{array}$ & $3 \mathrm{~d}$ pre-surgery & $\begin{array}{l}\text { SO/MCT }\left(\text { Lipovenoes }^{\mathbb{1}}\right) \\
(\mathrm{n}=32)\end{array}$ & $\begin{array}{l}\text { No effect on post-operative infections, length of } \\
\text { ICU or hospital stay. }\end{array}$ \\
\hline Tsekos et al. 2004 [100] & Gastrointestinal surgery & $\begin{array}{l}\text { Perioperative SO/MCT + FO }\left(\text { Omegaven }^{\circledR}\right) \\
(n=53) \text { vs Post-operative SO/MCT + FO } \\
\left(\text { Omegaven }^{\mathbb{\circledR}}\right)(\mathrm{n}=86)\end{array}$ & $\begin{array}{l}2-3 \text { d pre-surgery } \\
\text { followed by } 5 \\
\text { d post-surgery }\end{array}$ & $\begin{array}{l}\text { SO/MCT (brand un-disclosed) } \\
(\mathrm{n}=110)\end{array}$ & $\begin{array}{l}\text { Perioperative: } \\
\downarrow \text { Mortality } \\
\downarrow \text { Number of patients requiring ventilation } \\
\downarrow \text { Hospital stay } \\
\text { No change in length of ICU stay }\end{array}$ \\
\hline Umpierrez et al. 2012 [84] & Surgery & $\begin{array}{l}\mathrm{OO} / \mathrm{SO}\left(\text { ClinOleic }^{\circledR}\right) \\
(\mathrm{n}=51)\end{array}$ & $28 \mathrm{~d}$ post-surgery & $\begin{array}{l}\text { SO }\left(\text { Intralipid }^{\mathbb{\circledR}}\right) \\
(\mathrm{n}=49)\end{array}$ & $\begin{array}{l}\text { No difference in mortality, infections or length } \\
\text { of stay }\end{array}$ \\
\hline Wachtler et al. 1997 [207] & Gastrointestinal surgery & $\begin{array}{l}\left.\text { SO/MCT/FO (Prototype of Lipoplus }{ }^{\circledR}\right) \\
(n=19)\end{array}$ & $5 \mathrm{~d}$ post-surgery & $\begin{array}{l}\text { SO/MCT (brand un-disclosed) } \\
(\mathrm{n}=21)\end{array}$ & $\begin{array}{l}\text { Trend toward fewer infections and shorter ICU } \\
\text { stay. } \\
\text { No effect on length of hospital stay }\end{array}$ \\
\hline Wang et al. 2012 [104] & Gastrointestinal surgery & $\begin{array}{l}\left.\text { SO/MCT/FO (Lipoplus }{ }^{\mathbb{\circledR}}\right) \\
(\mathrm{n}=32)\end{array}$ & $5 \mathrm{~d}$ post-surgery & $\begin{array}{l}\text { SO/MCT }\left(\text { Lipofundin }^{\mathbb{B}}\right) \\
(\mathrm{n}=31)\end{array}$ & $\downarrow$ Total bilirubin \\
\hline Weiss et al. 2002 [90] & Surgery & Peri-operative FO $\left(\right.$ Omegaven $\left.^{\circledR}\right)(\mathrm{n}=12)$ & d-1 to d 5 & SO $\left(\right.$ Lipovenoes $\left.^{\circledR}\right)(\mathrm{n}=12)$ & $\begin{array}{l}\downarrow \text { Length of hospital stay. } \\
\text { No effect on infection rate or mortality. }\end{array}$ \\
\hline Wichmann et al. 2007 [96] & Gastrointestinal surgery & $\begin{array}{l}\left.\text { SO/MCT/FO (Lipoplus }{ }^{\circledR}\right) \\
(\mathrm{n}=127)\end{array}$ & $5 \mathrm{~d}$ post-surgery & $\begin{array}{l}\text { SO }\left(\text { Intralipid }{ }^{\circledR}\right) \\
(\mathrm{n}=129)\end{array}$ & $\begin{array}{l}\downarrow \text { Length of hospital stay. } \\
\text { Trend toward fewer infections and decreased } \\
\text { length of ICU stay. } \\
\text { No effect on mortality }\end{array}$ \\
\hline Wu et al. 2014 [110] & Gastrointestinal surgery & SO/MCT/OO/FO $\left(\right.$ SMOFlipid $\left.^{\mathbb{B}}\right)(\mathrm{n}=20)$ & $5 \mathrm{~d}$ post surgery & $\begin{array}{l}\text { MCT/SO }\left(\text { Lipovenoes }{ }^{\circledR}\right) \\
(\mathrm{n}=15)\end{array}$ & $\begin{array}{l}\text { No difference in infections, duration of hospital } \\
\text { stay or mortality }\end{array}$ \\
\hline Zhu et al. 2012 [93] & $\begin{array}{l}\text { Elderly gastrointestinal } \\
\text { surgery }\end{array}$ & $\begin{array}{l}\text { SO }+ \text { FO }\left(\text { Intralipid }^{\circledR}+\text { Omegaven }^{\circledR}\right) \\
(\mathrm{n}=29)\end{array}$ & $7 \mathrm{~d}$ post-surgery & SO $\left(\right.$ Intralipid $\left.{ }^{\mathbb{B}}\right)(\mathrm{n}=28)$ & $\begin{array}{l}\downarrow \text { Infectious complications } \\
\downarrow \text { SIRS } \\
\downarrow \text { Length of hospital stay }\end{array}$ \\
\hline
\end{tabular}


Table 6

Clinically relevant outcomes from including different lipid emulsions in PN in critically ill medical patients.

\begin{tabular}{|c|c|c|c|c|c|}
\hline Study & Population & Intervention & Duration & Control & Outcome \\
\hline $\begin{array}{l}\text { Barbosa et al. } 2010 \\
\text { [119] }\end{array}$ & $\begin{array}{l}\text { Critically ill } \\
\text { with } \\
\text { sepsis/SIRS }\end{array}$ & $\begin{array}{l}\text { SO/MCT/FO }\left(\text { Lipoplus }^{\circledR}\right) \\
(\mathrm{n}=13)\end{array}$ & $5 \mathrm{~d}$ & $\begin{array}{l}\text { SO/MCT (part of } \\
\left.\text { LipidSpecial }^{\circledR}\right) \\
(\mathrm{n}=10)\end{array}$ & $\begin{array}{l}\uparrow \mathrm{PO}_{2} / \mathrm{FiO}_{2} \text { ratio } \\
\downarrow \text { Length of hospital stay for surviving } \\
\text { patient sub-group. } \\
\text { No difference in ventilation days, length of } \\
\text { ICU stay or mortality }\end{array}$ \\
\hline $\begin{array}{l}\text { Barros et al. 2013, } \\
2014[208,209]\end{array}$ & $\begin{array}{l}\text { Elderly ICU } \\
\text { patients } \\
\text { on EN }\end{array}$ & $\begin{array}{l}\text { Supplementary FO } \\
\left(\text { Omegaven }^{\circledR}\right) \\
(\mathrm{n}=15)\end{array}$ & $\begin{array}{l}6 \mathrm{~h} \text { infusions/d } \\
\text { for } 3 \mathrm{~d}\end{array}$ & $\begin{array}{l}\text { No supplementary PN } \\
(\mathrm{n}=25)\end{array}$ & $\begin{array}{l}\uparrow \text { Gas exchange } \\
\text { Trend toward shorter length of mechanical } \\
\text { ventilation and decreased mortality. } \\
\text { No effect on liver function }\end{array}$ \\
\hline $\begin{array}{l}\text { Burkhart et al. } 2014 \\
{[120]}\end{array}$ & Sepsis & FO $\left(\right.$ Omegaven $\left.{ }^{\circledR}\right)(\mathrm{n}=25)$ & $7 \mathrm{~d}$ & Standard care $(\mathrm{n}=25)$ & $\begin{array}{l}\text { No difference in duration of ICU stay or } \\
\text { mortality }\end{array}$ \\
\hline $\begin{array}{l}\text { Edmunds et al. } \\
2014[115]\end{array}$ & $\begin{array}{l}\text { Mechanically } \\
\text { ventilated } \\
\text { critically ill }\end{array}$ & $\begin{array}{l}\text { FO-enriched lipids (SMOFlipid }{ }^{\circledR} \text {, } \\
\left.\text { Lipoplus }^{\circledR} \text { or Omegaven }{ }^{\circledR}\right) \\
(\mathrm{n}=19) \\
\text { OO/SO }\left(\text { ClinOleic }^{\circledR}\right)(\mathrm{n}=74)\end{array}$ & $\geq 5 \mathrm{~d}$ & $\begin{array}{l}\text { SO-based lipids (various } \\
\text { brands })(\mathrm{n}=223) \\
\text { Lipid-free }(\mathrm{n}=70) \\
\text { SO/MCT (various brands) } \\
(\mathrm{n}=65)\end{array}$ & $\begin{array}{l}\text { For FO-enriched lipids: } \\
\downarrow \text { Duration of mechanical ventilation } \\
\downarrow \text { Length of ICU stay } \\
\downarrow \text { Mortality }\end{array}$ \\
\hline $\begin{array}{l}\text { Friesecke et al. } \\
\quad 2008 \text { [126] }\end{array}$ & Medical ICU & $\begin{array}{l}\text { SO/MCT }+ \text { FO } \\
\left.\text { (Lipofundin }^{\circledR}+\text { Omegaven }^{\circledR}\right) \\
(\mathrm{n}=63)\end{array}$ & $\geq 6 \mathrm{~d}$ & $\begin{array}{l}\left.\text { SO/MCT (Lipofundin }{ }^{\circledR}\right) \\
(\mathrm{n}=60)\end{array}$ & $\begin{array}{l}\text { No effect on infection, duration of } \\
\text { mechanical ventilation, length of ICU stay or } \\
\text { 28-day mortality }\end{array}$ \\
\hline $\begin{array}{l}\text { García-de-Lorenzo } \\
\text { et al. } 2005 \text { [210] }\end{array}$ & Severe burns & OO/SO $\left(\right.$ ClinOleic $\left.^{\mathbb{R}}\right)(\mathrm{n}=11)$ & $6 \mathrm{~d}$ & $\begin{array}{l}\text { SO/MCT }\left(\text { Lipofundin }^{\circledR}\right) \\
(\mathrm{n}=11)\end{array}$ & $\begin{array}{l}\text { No effect on organ dysfunction, } \\
\text { requirement for ventilation, number of } \\
\text { infections, length of ICU or hospital stay or } \\
\text { mortality }\end{array}$ \\
\hline $\begin{array}{l}\text { Grau-Carmona } \\
\text { et al. } 2015 \text { [123] }\end{array}$ & $\begin{array}{l}\text { Medical and } \\
\text { surgical ICU }\end{array}$ & SO/MCT/FO $\left(\right.$ Lipoplus $\left.^{\circledR}\right)(\mathrm{n}=58)$ & $\geq 5 \mathrm{~d}$ & $\begin{array}{l}\text { SO/MCT }\left(\text { Lipofundin }^{\circledR}\right) \\
(\mathrm{n}=59)\end{array}$ & $\begin{array}{l}\downarrow \text { Nosocomial infections } \\
\text { No difference in duration of ventilation, } \\
\text { length of ICU or hospital stay or 6-month } \\
\text { mortality }\end{array}$ \\
\hline $\begin{array}{l}\text { Gupta et al. } 2011 \\
\text { [211] }\end{array}$ & ARDS on EN & $\begin{array}{l}\left.\text { Supplemental FO (Omegaven }{ }^{\circledR}\right) \\
(\mathrm{n}=31)\end{array}$ & $14 \mathrm{~d}$ & Standard EN $(\mathrm{n}=30)$ & $\begin{array}{l}\text { No difference in duration of ventilation, ICU } \\
\text { stay or hospital stay or mortality }\end{array}$ \\
\hline 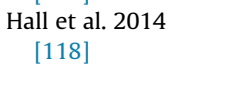 & $\begin{array}{l}\text { Critically ill } \\
\text { with sepsis }\end{array}$ & $\begin{array}{l}\text { FO }\left(\text { Omegaven }{ }^{(\mathbb{1}}\right) \\
(\mathrm{n}=30)\end{array}$ & $\begin{array}{l}14 \mathrm{~d} \text { or to } \\
\text { discharge }\end{array}$ & Standard care $(\mathrm{N}=30)$ & $\begin{array}{l}\downarrow \text { SOFA } \\
\downarrow \text { Mortality in less severe sepsis subgroup } \\
\text { No effect on length of stay }\end{array}$ \\
\hline $\begin{array}{l}\text { Khor et al. } 2011 \\
\quad[121]\end{array}$ & Severe sepsis & $\begin{array}{l}\left.\text { FO (Omegaven }{ }^{\circledR}\right) \\
(\mathrm{n}=14)\end{array}$ & $5 \mathrm{~d}$ & Saline $(n=13)$ & No effect on length of ICU or hospital stay \\
\hline $\begin{array}{l}\text { Mayer et al. } 2003 \\
\text { [122] }\end{array}$ & Septic shock & $\begin{array}{l}\text { FO }\left(\text { Omegaven }{ }^{\circledR}\right) \\
(\mathrm{n}=10)\end{array}$ & $5 \mathrm{~d}$ & SO $\left(\right.$ Lipoven $\left.^{\circledR}\right)(\mathrm{n}=11)$ & $\begin{array}{l}\text { No effect on mortality or length of } \\
\text { mechanical ventilation }\end{array}$ \\
\hline Mayer et al. 2003 & Septic shock & $\begin{array}{l}\text { FO }\left(\text { Omegaven }{ }^{\circledR}\right) \\
(\mathrm{n}=5)\end{array}$ & $10 \mathrm{~d}$ & SO $\left(\right.$ Lipoven $\left.^{\circledR}\right)(\mathrm{n}=5)$ & $\begin{array}{l}\text { Trend toward shorter ventilation time. } \\
\text { No mortality in either group }\end{array}$ \\
\hline $\begin{array}{l}\text { Sabater et al. } 2008 \\
\text { [212] }\end{array}$ & ARDS & SO/MCT/FO (Lipoplus $\left.{ }^{\circledR}\right)(\mathrm{n}=8)$ & $12 \mathrm{~h}$ & SO $\left(\right.$ Intralipid $\left.^{\circledR}\right)(\mathrm{n}=8)$ & No effect on gas exchange or mortality \\
\hline Wang et al. 2008 & $\begin{array}{l}\text { Acute } \\
\text { pancreatitis }\end{array}$ & $\begin{array}{l}\mathrm{SO}+\mathrm{FO} \\
\left(\text { Lipovenoes }^{\circledR}+\text { Omegaven }^{\circledR}\right) \\
(\mathrm{n}=20)\end{array}$ & $5 \mathrm{~d}$ & SO $\left(\right.$ Lipovenoes $\left.^{(\mathbb{R}}\right)(\mathrm{n}=20)$ & $\begin{array}{l}\downarrow \text { Requirement for renal replacement } \\
\text { therapy } \\
\uparrow \text { Oxygenation index } \\
\text { Trend toward fewer infections and shorter } \\
\text { length of ICU and hospital stay }\end{array}$ \\
\hline Zhu et al. 2012 [98] & $\begin{array}{l}\text { Liver } \\
\text { transplantation }\end{array}$ & $\begin{array}{l}\left.\text { FO (Omegaven }{ }^{\circledR}\right) \\
(\mathrm{n}=33)\end{array}$ & $\begin{array}{l}7 \mathrm{~d} \\
\text { post-surgery }\end{array}$ & $\begin{array}{l}\text { SO/MCT }(20 \% \text { emulsion } \\
\text { with a } 1: 1 \text { ratio }) \\
(\mathrm{n}=33)\end{array}$ & $\downarrow$ Length of hospital stay \\
\hline
\end{tabular}

SOFA, Sequential Organ Failure Assessment.

and may have been a factor in reducing ICU stay for patients at risk of sepsis. The newer composite SO/MCT/OO/FO (30:30:25:15) LE has also shown a liver-protecting effect in post-operative patients requiring $\mathrm{PN}$, resulting in significantly lower ALT, AST and $\alpha$-GST compared with OO/SO [107].

This liver-protective effect has also been demonstrated in liver transplantation patients, whereby post-operative FO-enriched PN lowered ALT and prothrombin time as well as length of hospital stay compared with PN containing SO/MCT [98]. Improvement in liver injury and a reduction in the number of infectious morbidities were also reported for the FO-enriched PN group.

It is important to note that not all clinical studies in surgical ICU patients have been positive. Parenteral SO/MCT/OO/FO administered to gastric cancer surgical patients resulted in no difference in efficacy, safety, tolerance or clinical outcomes (including postoperative complications) compared with SO/MCT [108]. Metry et al. also found no difference in ventilation requirement, duration of ICU or hospital stay or mortality following 7 days of postoperative administration of parenteral SO/MCT/OO/FO compared to SO alone [109]. Furthermore, Wu et al.'s study in gastrointestinal surgery patients found no difference in inflammatory markers (Creactive protein, IL-6, IL-10, TNF- $\alpha$ and transforming growth factor $\beta 1$ ) or markers of oxidative stress compared with SO/MCT [110].

A meta-analysis of 6 RCTs (306 surgical patients) did conclude that $\mathrm{SO} / \mathrm{MCT} / \mathrm{OO} / \mathrm{FO}$ was associated with lower hepatic enzymes, low-density lipoprotein, triglycerides and C-reactive protein following post-operative administration compared with SO, but found no statistically significant changes compared with SO/MCT [111]. There was no difference in adverse events or length of hospital stay compared with either SO or SO/MCT.

Eicosanoids are involved in the control of platelet aggregation and so influence blood clotting and bleeding time. TXA 2 and prostacyclin $\left(\mathrm{PGI}_{2}\right)$ are both produced from the omega-6 PUFA ARA. $\mathrm{TXA}_{2}$ is pro-aggregatory and $\mathrm{PGI}_{2}$ is anti-aggregatory. EPA from FO decreases the ARA content of the platelet membrane [112], so decreasing production of both $\mathrm{TXA}_{2}$ and $\mathrm{PGI}_{2}$ [112]. Instead, production of the EPA-derived eicosanoids $\mathrm{TXA}_{3}$, which is a weak platelet aggregator, and $\mathrm{PGI}_{3}$ which is a potent inhibitor of platelet 
Table 7

Clinical and biochemical outcomes from including different lipid emulsions in PN in pediatric patients.

\begin{tabular}{|c|c|c|c|c|c|}
\hline Study & Population & Intervention & Duration & Control & Outcome in intervention group \\
\hline $\begin{array}{l}\text { Beken et al. } 2014 \\
\text { [159] }\end{array}$ & $\begin{array}{l}\text { Very low birth } \\
\text { weight preterm } \\
\text { infants }\end{array}$ & $\begin{array}{l}\text { SO/MCT/OO/FO } \\
\left(\text { SMOFlipid }^{\circledR}\right) \\
(\mathrm{n}=40)\end{array}$ & Mean: $14 \mathrm{~d}$ & $\begin{array}{l}\left.\text { SO (Intralipid }{ }^{\circledR}\right) \\
(\mathrm{n}=40)\end{array}$ & $\begin{array}{l}\downarrow \text { Retinopathy of prematurity } \\
\text { No difference in morbidity or mortality } \\
\text { outcomes }\end{array}$ \\
\hline $\begin{array}{l}\text { D'Ascenzo et al. } \\
\quad 2014 \text { [160] }\end{array}$ & $\begin{array}{l}\text { Very low birth } \\
\text { weight preterm } \\
\text { infants }\end{array}$ & $\begin{array}{l}\text { SO/MCT/OO/FO } \\
\left(\text { SMOFlipid }^{\circledR}\right) \\
(\mathrm{n}=30)\end{array}$ & $7 \mathrm{~d}$ following birth & $\begin{array}{l}\left.\text { SO (Intralipid }{ }^{\circledR}\right) \\
(\mathrm{n}=32)\end{array}$ & $\begin{array}{l}\uparrow \text { Plasma EPA and DHA } \\
\downarrow \text { Plasma ARA } \\
\uparrow \text { Serum triglycerides, plasma } \\
\text { phospholipids, free cholesterol } \\
\text { No difference in weight. }\end{array}$ \\
\hline $\begin{array}{l}\text { Deshpande et al. } \\
2014[161]\end{array}$ & Preterm neonates & $\begin{array}{l}\text { SO/MCT/OO/FO } \\
\left(\text { SMOFlipid }^{\circledR}\right) \\
(n=17)\end{array}$ & $7 \mathrm{~d}$ & $\begin{array}{l}\text { OO/SO }\left(\text { ClinOleic }^{\circledR}\right) \\
(\mathrm{n}=17)\end{array}$ & $\begin{array}{l}\uparrow \mathrm{RBC} \text { EPA } \\
\uparrow \text { Vitamin E } \\
\downarrow \mathrm{F}_{2} \text { isoprostanes }\end{array}$ \\
\hline $\begin{array}{l}\text { Larsen et al. } 2012 \\
\quad[166]\end{array}$ & $\begin{array}{l}\text { Infants undergoing } \\
\text { open heart surgery }\end{array}$ & $\begin{array}{l}\text { SO/MCT/FO }\left(\text { Lipoplus }^{\circledR}\right) \\
(\mathrm{n}=16)\end{array}$ & $\begin{array}{l}1-4 \mathrm{~d} \text { before and } \\
10 \mathrm{~d} \text { post-surgery }\end{array}$ & $\begin{array}{l}\left.\text { SO (Intralipid }{ }^{\circledR}\right) \\
(\mathrm{n}=16)\end{array}$ & $\begin{array}{l}\downarrow \text { TNF- } \alpha \\
\text { No difference in clinical outcomes }\end{array}$ \\
\hline $\begin{array}{l}\text { Larsen et al. } 2015 \\
\quad[165]\end{array}$ & $\begin{array}{l}\text { Infants undergoing } \\
\text { open heart surgery }\end{array}$ & $\begin{array}{l}\left.\text { SO/MCT/FO (Lipoplus }{ }^{\circledR}\right) \\
(\mathrm{n}=16)\end{array}$ & $\begin{array}{l}3 \mathrm{~d} \text { pre-op and } 5 \mathrm{~d} \\
\text { post-op }\end{array}$ & $\begin{array}{l}\left.\text { SO (Intralipid }{ }^{\circledR}\right) \\
(\mathrm{n}=16)\end{array}$ & $\begin{array}{l}\uparrow \text { Plasma phospholipid EPA } \\
\downarrow \text { Plasma } \mathrm{LTB}_{4} \text { and lymphocytes }\end{array}$ \\
\hline $\begin{array}{l}\text { Pawlik et al. } 2013 \\
\text { [162] }\end{array}$ & $\begin{array}{l}\text { Very low } \\
\text { birthweight } \\
\text { preterm infants }\end{array}$ & $\begin{array}{l}\mathrm{OO} / \mathrm{SO}+\mathrm{FO} \\
\left(\mathrm{ClinOleic}^{\circledR}+\text { Omegaven }^{\circledR}\right) \\
(\mathrm{n}=60)\end{array}$ & $28 \mathrm{~d}$ & $\begin{array}{l}\text { OO/SO }\left(\text { ClinOleic }^{\circledR}\right) \\
(\mathrm{n}=70)\end{array}$ & $\begin{array}{l}\uparrow \text { Plasma DHA } \\
\downarrow \text { Cholestasis }\end{array}$ \\
\hline $\begin{array}{l}\text { Savini et al. } 2013 \\
\text { [163] }\end{array}$ & $\begin{array}{l}\text { Very low } \\
\text { birthweight } \\
\text { preterm infants }\end{array}$ & $\begin{array}{l}\text { SO }\left(\text { Intralipid }^{\circledR}\right)(\mathrm{n}=30) \text { vs } \\
\text { SO/MCT }\left(\text { Lipofundin }^{\circledR}\right) \\
(\mathrm{n}=30) \text { vs SO/MCT/FO } \\
\left(\text { Lipidem }^{\circledR}\right)(\mathrm{n}=27) \text { vs } \\
\text { OO/SO }\left(\text { ClinOleic }^{\circledR}\right)(\mathrm{n}=29) \\
\text { vs SO/MCT/OO/FO } \\
\left(\text { SMOFlipid }^{\circledR}\right)(\mathrm{n}=28)\end{array}$ & $21 \mathrm{~d}$ & - & $\begin{array}{l}\text { Lowest plasma phytosterols in } \\
\text { SMOFlipid }{ }^{\circledR} \text { group } \\
\text { No difference in liver function }\end{array}$ \\
\hline $\begin{array}{l}\text { Vlaardingerbroek } \\
\text { et al. } 2014 \text { [158], } \\
\text { Roelands et al. } \\
2016[134]\end{array}$ & $\begin{array}{l}\text { Very low birth } \\
\text { weight infants }\end{array}$ & $\begin{array}{l}\text { SO/MCT/OO/FO } \\
\left(\mathrm{SMOFlipid}^{\circledR}\right) \\
(\mathrm{n}=48)\end{array}$ & Median: $11 \mathrm{~d}$ & $\begin{array}{l}\left.\text { SO (Intralipid }{ }^{\circledR}\right) \\
(\mathrm{n}=48)\end{array}$ & $\begin{array}{l}\uparrow \text { Plasma EPA and DHA } \\
\uparrow \text { Weight gain } \\
\text { No difference in ARA. } \\
\text { No differences in morbidity, mortality } \\
\text { or other biochemical outcomes } \\
\text { No difference in neurodevelopmental } \\
\text { outcome }\end{array}$ \\
\hline $\begin{array}{l}\text { Wang et al. } 2016 \\
\text { [164] }\end{array}$ & Preterm infants & OO/SO $\left(\right.$ ClinOleic $\left.^{\circledR}\right)(n=50)$ & $14 \mathrm{~d}$ & $\begin{array}{l}\left.\text { SO (Intralipid }{ }^{\circledR}\right) \\
(\mathrm{n}=50)\end{array}$ & $\begin{array}{l}\downarrow \text { Direct bilirubin } \\
\text { Differences in bile acid composition } \\
\text { No difference in clinical outcome }\end{array}$ \\
\hline
\end{tabular}

aggregation occurs [112]. Thus, FO results in decreased platelet aggregation [112], which can increase bleeding and time to clotting. With regard to this theoretical increased risk of bleeding with FObased PN, studies to date have shown that FO is safe to include in PN regimens and does not increase risk of bleeding. Acute pretreatment with omega-3 PUFAs in coronary artery bypass graft patients non-significantly affected the activity of platelets and did not influence postoperative blood loss [113].

Based on the evidence available and according to the new ESPEN guidelines on clinical nutrition in surgery, postoperative PN including omega-3-fatty acids should be started only in malnourished patients who cannot be adequately fed enterally and, therefore, require PN [114]. If PN is required post-operatively in the ICU, 2nd or 3rd generation lipid emulsions may be administered, and in the case of surgical complications, FO-containing $\mathrm{PN}$ is recommended.

\subsubsection{Fish oil-enriched $P N$ in non-surgical ICU patients}

Compared to SO and SO/MCT, FO-enriched PN may provide clinical benefits for a wide range of ICU patients. In mechanically ventilated critically ill patients, FO-enriched PN resulted in a shorter duration of mechanical ventilation and a faster time to ICU discharge compared to lipid-free or SO-based PN [115]. In patients with acute pancreatitis, administration of FO-supplemented PN resulted in significantly decreased CRP in addition to better oxygenation index and fewer days of continuous renal replacement therapy compared with SO alone [116].

Clinical studies in patients with sepsis have shown that parenteral administration of either omega- 6 or omega- 3 fatty acids results in elevated concentrations of the respective free fatty acids several-fold, as well as appearance of the respective eicosanoids [117]. Hence PN containing FO should theoretically lead to increased levels of inflammation-resolving resolvins and associated clinical benefits. The latter is supported by some trials. Compared to standard care, FO administered to patients with sepsis resulted in a significant reduction in new organ dysfunction and lower maximum C-reactive protein concentrations [118]. A significant reduction in mortality was observed for patients with less severe sepsis. Furthermore, FO-enriched PN (SO/MCT/FO 50:40:10) administered to patients with sepsis or SIRS for 5 days increased plasma EPA levels, decreased plasma IL-6, improved oxygenation $\left(\mathrm{PO}_{2} / \mathrm{FiO}_{2}\right.$ ratio) and reduced length of hospital stay compared to SO/MCT [119]. However, several studies have failed to show any clinical benefit of FO-enriched PN in cases of sepsis or septic shock compared to either standard care, saline or SO-based PN [117,120-122], although one of these studies did find a nonstatistically significant trend toward shorter ventilation time [117].

FO-enriched PN administered to critically ill medical and surgical patients may result in a significant reduction in the number of nosocomial infections compared to SO/MCT [123]. Time free of infection was also significantly longer in the FO-supplemented group, although there was no effect reported for ICU or hospital stay or 6-month mortality rate.

This lack of effect of FO-enriched PN on mortality rate compared to standard PN is confirmed by meta-analyses of 6 RCTs [124] and of 8 RCTs [125] in critically ill adults, the latter also finding no difference in infectious complications or ICU length of stay. There was weak evidence of a reduction of hospital length of stay associated with FO-enriched PN, but this was strongly influenced by one small study [125]. 
Not all trials investigating the use of FO-enriched PN in critically ill patients report positive outcomes. Administration of FOenriched PN to medical ICU patients (with and without SIRS) had no effect on inflammatory markers (IL-6), incidence of infection, duration of mechanical ventilation, length of ICU stay or 28-day mortality compared with SO/MCT [126]. The study included severely ill patients that were at different stages of the inflammation/inflammation resolution cycle; hence the intervention may have been administered after termination of the initial inflammatory process in some patients. Timing of omega- 3 fatty acid administration is important if hyper-inflammation is to be prevented, and from previously discussed studies, administration prior to commencement of inflammation is likely optimal. Furthermore, dosage levels of the administered FO also play a critical role in whether the intervention provides clinical benefit. A study investigating the dose-dependent effects of FO-enriched PN in a range of ICU patients found that the most favorable effects on survival, infection rates and length of hospital stay occurred when parenteral FO was administered between 0.1 and $0.2 \mathrm{~g} / \mathrm{kg} / \mathrm{d}$. A 26\% lower antibiotic demand was associated with parenteral administration of FO between 0.15 and $0.20 \mathrm{~g} / \mathrm{kg} / \mathrm{d}$ [127].

\section{Lipids and PN in pediatric patients}

The joint European Society for Paediatric Gastroenterology, Hepatology and Nutrition (ESPGHAN) and ESPEN guidelines on PN in pediatrics recommend that in small preterm infants, when EN is not possible, PN including lipids should be initiated as soon as possible after birth [128]. Intolerance to full EN is common in preterm infants, and results in a high incidence of postnatal growth failure.

Surveys of current practice in neonatal ICUs in Europe and the US show that there is a wide range in the timing and initial dose of lipid administration [129]. In the UK and Ireland, whilst a greater proportion of preterm infants start PN within $48 \mathrm{~h}$, around one quarter of preterm infants still are not given PN until or after day 3 [130]. When considering a role for PN and lipids in preterm infants, the potential to improve neurodevelopmental outcomes should not be overlooked: DHA is critical in neurodevelopment with the brain comprising $60 \%$ of lipid, and with $>80 \%$ of brain DHA accumulating between 26 and 40 weeks gestation [131].

In preterm infants, there is concern regarding early lipidcontaining PN and the risk of complications such as sepsis, bronchopulmonary dysplasia (BPD), hyperbilirubinemia, liver disease, persistent pulmonary hypertension of the newborn (PPHN) and thrombocytopenia. However, a meta-analysis of 14 studies investigating the effect of early ( $\leq 2 \mathrm{~d}$ ) parenteral lipid in very low birth weight (VLBW) infants, found no difference in sepsis, BPD, growth or mortality rates compared to later ( $\geq 2 \mathrm{~d}$ ) administration [132]. This is supported by a later RCT comparing lipid-containing PN administered from birth to VLBW infants with standard PN from birth with lipids administered 2 d later, which reported no difference in growth, biochemical or clinical outcomes between the groups [133,134].

There is also a risk of hypertriglyceridemia associated with lipid administration in preterm infants, due to limited fat and muscle mass and thus decreased hydrolytic capacity from lipoprotein lipase. Whilst there is no specific indicator of lipid tolerance, as plasma triglyceride levels indicate plasma clearance, monitoring of plasma triglycerides is recommended. ESPGHAN recommends a safe triglyceride level of $2.85 \mathrm{mmol} / \mathrm{l}(250 \mathrm{mg} / \mathrm{dl})$ in preterm infants and newborns [128], whilst ASPEN recommends $2.26 \mathrm{mmol} / \mathrm{l}$ $(200 \mathrm{mg} / \mathrm{dl})$ [135]. However, in one trial, hypertriglyceridemia of $>3 \mathrm{mmol} / \mathrm{l}(>265 \mathrm{mg} / \mathrm{dl})$ was not associated with neonatal morbidities [133].
IFALD is associated with chronic ( $>14 \mathrm{~d}$ ) total PN (TPN), and incidence is directly related to TPN duration. Short bowel syndrome (SBS) accounts for $1.4 \%$ of all deaths for children under $4 \mathrm{y}$ and is primarily related to the development of IFALD which is identified through biochemical parameters such as direct bilirubin levels $>2 \mathrm{mg} / \mathrm{dl}(34 \mu \mathrm{mol} / \mathrm{l})$, increased GGT, ALT, and serum bile acids $[136,137]$. Some $40-60 \%$ of patients with short bowel syndrome on TPN develop cholestasis, and a study published in 2005 reported that the mortality rate is approximately $78 \%$ if bilirubin remains $>3 \mathrm{mg} / \mathrm{dl}$ for 3 months, and increases to $90 \%$ if cholestasis is diagnosed and there is no weaning off TPN within a year of diagnosis, or failure to receive a liver transplant [138]. A Pediatric Intestinal Failure Consortium (PIFCon) retrospective analysis of clinical outcome data for infants with intestinal failure reported that of a cohort of 272 infants $(<1 \mathrm{y}$ old and on prolonged TPN for $>2$ months), the mortality rate was $27 \%$ and intestinal transplantation rate was 26\% [139].

Besides prematurity and prolonged TPN use, other risk factors for IFALD include lack of enteral nutrition, multiple operative procedures, sepsis or inflammation, and possibly also nutrient deficiencies or toxicities associated with other components in lipid PN $[140,141]$. Preventative/treatment measures for IFALD may include cycling PN, feed advancement, prevention and aggressive treatment of sepsis, lipid reduction to $\leq 1 \mathrm{~g} / \mathrm{kg} / \mathrm{d}$, altering the lipid being used in PN (see below), elimination of hepatotoxic medications, reduction of bacterial overgrowth, use of the bile acid ursodiol, reduction of transfusions and minimizing surgical procedures if possible [137,142-151], although the evidence in favor of some of these is weak [152]. Whilst IFALD/cholestasis may be reversed with elimination/reduction of lipids, cholestasis may be progressive whilst on PN. It may lead to liver cirrhosis, liver failure, liver transplant or death [153].

Regarding the choice of LE in PN for pediatric patients, it is suggested that high levels of omega-6 PUFAs and phytosterols found in SO can be hepatotoxic and lead to IFALD [154]. Phytosterols have been shown to antagonize the farnesoid-X-receptor (FXR) [155] which normally acts to suppress hepatic lipogenesis and bile acid synthesis. Thus, in the presence of phytosterols, those processes continue uncontrolled leading to both fatty liver and cholestasis. FO-containing PN may have a protective effect against IFALD due to the lower phytosterol content, higher omega-3 PUFA content, and higher $\alpha$-tocopherol content, and to direct regulation of bile flow through eicosanoid-mediated mechanisms [156]. In pediatric patients with IFALD whose cholestasis was resolved with use of FO, decreased direct bilirubin levels and markers of liver injury were reported together with improvement in hepatic function [156,157]. However, some of these studies compared a group of infants receiving FO-based PN with an historic control group. Furthermore, some studies used pure FO LE rather than a lipid mix. Finally, many studies have lowered the lipid dose being used (generally to $1 \mathrm{~g} / \mathrm{kg} / \mathrm{d}$ ) at the same time as introducing FOcontaining PN. Thus, it is difficult to disentangle the effects of the lower lipid dose from those of an alternative lipid mixture.

With regard to other potential clinical benefits of FO-enriched PN in preterm infants, an RCT in VLBW infants administered SO/ $\mathrm{MCT} / \mathrm{OO} / \mathrm{FO}$ reported a significant increase in weight gain and increased plasma EPA and DHA (but no difference in ARA) compared to SO-based PN $[134,158]$. However, there were no differences in morbidity, mortality or biochemical outcomes between the two groups. Several studies concur regarding these outcomes with multi-component lipid PN versus other LEs [158-164].

FO-enriched PN given to infants undergoing major cardiac surgery may help ameliorate the post-operative inflammatory response. A study investigating the effects of parenteral SO/MCT/FO (40:50:10) given pre- and post-operatively to infants undergoing 
open heart surgery reported a lower inflammatory response postsurgery compared with SO alone [165]. Specifically the FO containing LE resulted in higher plasma phospholipid EPA and decreased plasma $\mathrm{LTB}_{4}$ and lymphocytes. An earlier trial also found significantly lower TNF- $\alpha$ concentrations and a positive association with length of hospital stay in the SO/MCT/FO group compared with SO when given perioperatively in infants undergoing cardiac surgery [166].

In summary, for preterm infants, lipids given directly following birth at $2 \mathrm{~g} / \mathrm{kg} / \mathrm{d}$ appear safe according to short term studies. Emulsions with a mix of lipid sources including FO may offer benefits over SO alone, although long-lasting positive effects need to be proven.

\section{Economic considerations for fish oil-enriched lipids in the ICU}

Pradelli et al. performed an analysis of the cost-effectiveness of $\mathrm{SO} / \mathrm{MCT} / \mathrm{OO} / \mathrm{FO}$ in surgical and ICU patients in four European countries (Italy, Germany, France and the UK) [167]. The analysis considered costs associated with nutritional treatment, ICU stay, general ward stay and nosocomial infections as well as the benefits of FO-containing PN on infection rates and length of stay. The study concluded that the treatment costs associated with FO-enriched PN were completely offset by the savings made from the subsequent reduction in hospital stay and reduced antibiotic costs. Hence, FOcontaining PN is cost-effective and beneficial for both ICU and nonICU patients in hospitals in Italy, Germany, France and the UK compared with standard PN.

\section{Future directions}

\subsection{Effects of omega-3 fatty acids in preclinical models of acute neurological injury}

Spinal cord injury (SCI) is associated with significant social and healthcare burden [168]. In the acute phase following SCI, the initial lesion expands and results in a secondary injury wave, reflected in the progressive loss of gray matter within the spinal cord $[169,170]$. Secondary injury pathophysiology is characterized by activation of inflammatory pathways, increased glutamate release and vascular damage leading to ischemia [171]. Preclinical studies involving rodent compression and hemisection SCI models, at thoracic and cervical levels, have demonstrated that acute DHA injection in the range of $250-500 \mathrm{nmol} / \mathrm{kg}$ body weight, with or without sustained dietary supplementation, has a neuroprotective effect and improves neurological outcomes [172-177]. Specifically, DHA administration results in a reduced lesion size and less inflammation (including TNF- $\alpha$ expression), reduced neuronal, oligodendrocyte and neurofilament loss, reduced macrophage/microglia recruitment and activation, and less apoptotic death, and this is correlated with an improved locomotor recovery [172-176]. DHA appears to enhance motor function recovery via its effect on the serotonin fiber input on motor neurons [177]. DHA also has a positive effect on synaptic remodeling and may enhance synaptogenesis. Immunoreactivity of synaptophysin, a synaptic vesicle protein, was found to be less reduced after injury in DHA-treated animals compared with controls, in a rat model of cervical SCI [177].

With regard to traumatic brain injury (TBI), in the US there are 1.5-2 million new cases per year, accounting for 30\% of injuryrelated deaths, with an annual cost of $\$ 25$ billion [178]. TBI, particularly repetitive, increases susceptibility to Alzheimer's disease, as evidenced in murine models, where repetitive TBI resulted in increased amyloid $\beta$-deposition, isoprostanes and cognitive impairment [179]. However, acute DHA administration $(500 \mathrm{nmol} /$ kg body weight) 30 min after controlled cortical impact can improve spatial memory [180]. In terms of the mechanisms involved, TBI and SCI are both associated with glutamate overflow which may be controlled via omega-3 PUFA through inhibition of voltage-sensitive $\mathrm{Na}^{+}$and $\mathrm{Ca}^{2+}$ channels and activation of $\mathrm{K}^{+}$ channels [181].

DHA may also be a future treatment option for patients with stroke. In rodent ischemic stroke models, DHA administration, acting via biosynthesis of neuroprotectin D1 (aka protectin D1), reduces astrocyte and neuronal cell death and promotes cell survival, resulting in significantly reduced total infarct volume [182,183].

Preclinical rodent models have also shown that the improved neurological outcome following acute DHA injection is not only associated with neuronal survival. Indeed, controlled cortical impact models in mice have demonstrated that ablation of astrocytes resulted in decreased neuronal survival, and increased neuroinflammation [184]. Hence, a subset of astrocytes appears to have a role in aiding neuronal survival and reducing inflammation after brain injury [185]. It has also been demonstrated that after mild compression injury in mice, heterogeneity of microglia at the site develops alongside a coordinated microglial response [186]. Following TBI, there is upregulation of a sub-population of microglia that express galectin-3/MAC-2 lectins that are involved in myelin degradation [187]. Hence the acute DHA administration appears to play a role in modulating this complex glial response, e.g. by increasing these new and proliferating microglia and astrocytes, and ultimately resulting in decreased lesion volume.

In humans, following a single TBI, there is evidence of persistent neuroinflammation and microglial activation for up to 17 years afterward [188,189]. This suggests that interventions using DHA may be appropriate for a longer time period following TBI rather than just in the acute phase.

In summary, preclinical models of SCI and TBI suggest that DHA, if administered in the acute phase and for some time afterward, may help to limit progression of neurological injury and improve neurological outcomes.

\subsection{Effects of omega-3 fatty acids in preclinical models of sepsis and tissue injury}

Omega-3 fatty acids have been shown to have a protective effect against edema formation in a model of septic lung failure due to the increased generation of $\mathrm{LTB}_{5}$. In perfused rabbit lung treated with Escherichia coli hemolysin, EPA suppressed vascular permeability and shifted leukotriene formation from the 4-series to the 5-series compared to ARA [190]. Hence, the composition of LEs used in PN may influence microvascular changes induced by bacterial toxins.

The favorable lipid mediators formed from EPA may also have a beneficial effect on pulmonary hypertension compared to those formed from ARA. In a rabbit lung model of acute pulmonary hypertension investigating the pulmonary vasoconstrictor potencies of EPA and ARA, EPA resulted in an almost 2-fold decrease in pulmonary hypertension compared to ARA [191]. EPA is metabolized to $\mathrm{PGI}_{3}$ and $\mathrm{TXA}_{3}$ and it may be that the dominant presence of $\mathrm{TXA}_{3}$ mediates EPA's weaker pulmonary vasoconstrictor effects, compared with ARA and ARA-derived TXA2.

In inflammatory conditions, particularly systemic inflammation with sepsis and multi-organ failure, the transmigration of monocytes through the vascular endothelium is an important contributing factor to the pathogenesis of the condition. In an in vitro experiment investigating the effect of different free fatty acids on TNF- $\alpha$ activated human umbilical vein endothelial cells, EPA and DHA (but not ARA), resulted in markedly suppressed plateletactivating factor (PAF), resulting in reduced monocyte rolling and 
adherence, with DHA being more potent than EPA [192]. Previous work has suggested that the binding of endothelial PAF and the PAF receptor on leukocytes are responsible for the adhesive interactions of monocytes followed by their activation [193]. This mechanism involving PAF may be one factor responsible for the inflammationdampening effect of EPA and DHA.

In a murine model of acute inflammation, pre-infusion of FOrich LE resulted in reduced leukocyte invasion and reduced TNF- $\alpha$ production in the alveolar space following intra-tracheal LPS challenge, compared with SO or saline [194]. In PAF-receptor knock-out mice, the different effects of FO and SO were far less marked. This supports the hypothesis that the anti-inflammatory effect of FO is dependent on PAF/PAF-receptor linked signaling. Similarly, in a murine model of ARDS, pre-infusion with FOcontaining LE resulted in greater reduction of leukocyte invasion and protein leakage into the alveolar space than either SO or SO/ MCT [195]. These results suggest that the reduction in the proportion of omega-6 PUFA administered may help improve lung injury.

Extensive lymphocytic apoptosis is a hallmark feature of latestage sepsis, and can be clearly seen in the spleen as well as other organs [196]. In a murine model of endotoxin-induced ALI, OO pre-infusion resulted in less mortality compared with SO preinfusion [197]. Fewer lymphocytes were observed in the spleen in the SO group which appeared to be due to increased apoptosis and necrotic cell death, although both LEs resulted in increased lymphocytic apoptosis via intrinsic pathways. Hence, OO-based LEs may have fewer deleterious immunological effects than SO, at least in murine models of ALI.

In critically ill patients, a reduced flow of blood to the gut can lead to intestinal ischemia, decreased barrier function and increased bacterial translocation. A rat endotoxin model investigating the effects of different lipid pre-infusions on microcirculation and intestinal barrier function reported improved blood flow to the intestine and less viable bacteria detected in the mesenteric lymph nodes and liver following endotoxin challenge with FOsupplemented SO/MCT compared with SO/MCT or SO alone [198]. The reduction in viable bacteria is thought to be related to improved killing of translocated bacteria rather than a reduction in translocation.

In healthy human volunteers, infusion of FO blunted the endotoxin-induced inflammatory response including suppression of monocyte generation of pro-inflammatory cytokines (TNF- $\alpha$, IL1, IL-6 and IL-8), and inhibition of monocyte-endothelium adhesion and transendothelial monocyte migration compared to SO [199]. Decreased fever in response to LPS, reduced TNF- $\alpha$ synthesis and a reduced LPS-induced neuroendocrine response (ACTH and noradrenaline) have also been observed with FO infusion in humans [200]. Similar protective results have been found after preinfusion of either SO- or FO-based lipid emulsions and subsequent LPS-inhalation [201].

In summary, from preclinical models, different lipids may impact the inflammatory response of critically ill patients. SO LEs may exert negative effects in terms of increased pro-inflammatory cytokines and immune depression, such as lymphocyte destruction, whereas FO appears to dampen the inflammatory response and improve pre-clinical outcomes.

\section{Conclusion}

Lipids are an important component of enteral and parenteral nutrition and provide essential fatty acids, a concentrated source of calories and building blocks for cell membranes. Whilst LA-rich vegetable oil-based enteral and parenteral nutrition is still widely used, newer lipid components such as MCTs and OO appear to be safer and better tolerated than pure SO. FO-enriched enteral and parenteral nutrition appears to be well tolerated and confers additional clinical benefits, particularly in surgical ICU patients, due to its anti-inflammatory and immune-modulating effects. Whilst the evidence base is not conclusive, there appears to be a potential for FO-enriched nutrition, particularly administered perioperatively, to reduce the rate of complications and ICU and hospital stay in surgical ICU patients, as well as to improve complications such as IFALD associated with SO-based LEs. The evidence for FO-based nutrition in non-surgical ICU patients is less clear regarding its clinical benefits and additional, well-designed largescale clinical trials need to be conducted in this area.

Whilst FO-based PN can be more expensive than other available LEs, cost-benefit analysis has shown that the treatment costs for ICU patients are completely offset by the savings made from the subsequent reduction in hospital stay and reduced antibiotic costs.

Future directions regarding FO-based enteral and parenteral nutrition may include its use in TBI and SCI, as well as in complications relating to sepsis and tissue injury, following the success of such interventions in preclinical models.

\section{Conflicts of interest}

P.C.C. has received speaking and advisory honoraria from Fresenius-Kabi, B. Braun, Baxter Healthcare, Abbott Nutrition and Danone/Nutricia. M.A. has received speaking honoraria from B. Braun, Cosmed and Danone/Nutricia. N.E.D. has received speaking and advisory honoraria from Abbott Nutrition. T.G. has received speaking honoraria from B. Braun and Fresenius-Kabi. S.K. has received speaking honoraria from Fresenius-Kabi, B. Braun, Baxter Healthcare, Nutricia Poland, Nestle and Shire. S.L has received speaking honoraria from Fresenius-Kabi, Baxter Healthcare and Abbott Nutrition, K.M. has received speaking honoraria from Fresenius-Kabi, B. Braun, Baxter Healthcare, Abbott Nutrition, and Nestlé. A.M-T. has received grant funding from B. Braun. L.P. has received speaking honoraria and grants from Fresenius-Kabi, Amgen, CSL Behring, Gilead Sciences, GlaxoSmithKline, JanssenCilag, Novartis, Roche, Sorin Group, and Viiv Healthcare. M.P. holds an issued patent on the treatment of parenteral nutritionassociated liver disease: a license agreement for the use of Omegaven has been signed by Boston Children's Hospital and Fresenius Kabi. P.S. has received speaking honoraria and grants from Fresenius-Kabi, B. Braun, Baxter Healthcare and Abbott Nutrition. J.K.I. and H.V. have no conflicts to declare.

\section{References}

[1] Singer P, Hiesmayr M, Biolo G, Felbinger TW, Berger MM, Goeters C, et al. Pragmatic approach to nutrition in the ICU: expert opinion regarding which calorie protein target. Clin Nutr 2014;33:246-51. http://dx.doi.org/10.1016/ j.clnu.2013.12.004.

[2] Alkhawaja S, Martin C, Butler RJ, Gwadry-Sridhar F. Post-pyloric versus gastric tube feeding for preventing pneumonia and improving nutritional outcomes in critically ill adults. Cochrane Database Syst Rev 2015;8. http:// dx.doi.org/10.1002/14651858.CD008875.pub2. CD008875.

[3] Kreymann KG, Berger MM, Deutz NEP, Hiesmayr M, Jolliet P, Kazandjiev G, et al. ESPEN guidelines on enteral nutrition: intensive care. Clin Nutr 2006;25:210-23. http://dx.doi.org/10.1016/j.clnu.2006.01.021.

[4] McClave SA, Martindale RG, Vanek VW, Mccarthy M, Roberts P, Taylor B, et al. Guidelines for the provision and assessment of nutrition support therapy in the adult critically ill patient: Society of Critical Care Medicine and American Society for Parenteral and Enteral Nutrition. Crit Care Med 2009;37:1-30. http://dx.doi.org/10.1097/CCM.0b013e3181a40169.

[5] Reintam Blaser A, Starkopf J, Alhazzani W, Berger MM, Casaer MP, Deane AM, et al. Early enteral nutrition in critically ill patients: ESICM clinical practice guidelines. Intensive Care Med 2017;43:380-98. http://dx.doi.org/10.1007/ s00134-016-4665-0.

[6] Doig GS, Chevrou-Séverac H, Simpson F. Early enteral nutrition in critical illness: a full economic analysis using US costs. Clin Outcomes Res 2013;5: 429-36. http://dx.doi.org/10.2147/CEOR.S50722. 
[7] McClave SA, Martindale RG, Rice TW, Heyland DK. Feeding the critically ill patient. Crit Care Med 2014;42:2600-10. http://dx.doi.org/10.1097/ CCM.0000000000000654.

[8] Huynh D, Chapman M, Nguyen N. Nutrition support in the critically ill. Curr Opin Gastroenterol 2013;29:208-15. http://dx.doi.org/10.1097/MOG.0b0 13 e32835c9c83.

[9] Artinian V, Krayem H, DiGiovine B. Effects of early enteral feeding on the outcome of critically ill mechanically ventilated medical patients. Chest 2006;129:960-7. http://dx.doi.org/10.1378/chest.129.4.960.

[10] Doig GS, Heighes PT, Simpson F, Sweetman EA, Davies AR. Early enteral nutrition, provided within $24 \mathrm{~h}$ of injury or intensive care unit admission, significantly reduces mortality in critically ill patients: a meta-analysis of randomised controlled trials. Intensive Care Med 2009;35:2018-27. http:// dx.doi.org/10.1007/s00134-009-1664-4.

[11] Doig GS, Heighes PT, Simpson F, Sweetman EA. Early enteral nutrition reduces mortality in trauma patients requiring intensive care: a meta-analysis of randomised controlled trials. Injury 2011;42:50-6. http://dx.doi.org/ 10.1016/j.injury.2010.06.008.

[12] Cederholm T, Barazzoni R, Austin P, Ballmer P, Biolo G, Bischoff SC, et al. ESPEN guidelines on definitions and terminology of clinical nutrition. Clin Nutr 2016;36:49-64. http://dx.doi.org/10.1016/j.clnu.2016.09.004.

[13] Singer P, Berger MM, Van den Berghe G, Biolo G, Calder P, Forbes A, et al. ESPEN guidelines on parenteral nutrition: intensive care. Clin Nutr 2009;28: 387-400. http://dx.doi.org/10.1016/j.clnu.2009.04.024

[14] Simpson F, Doig GS. Parenteral vs. enteral nutrition in the critically ill patient: a meta-analysis of trials using the intention to treat principle. Intensive Care Med 2005;31:12-23. http://dx.doi.org/10.1007/s00134-004-2511-2.

[15] Casaer M, Mesotten D, Hermans G, Wouters P, Schetz M, Meyfroidt G, et al. Early versus late parenteral nutrition in critically ill adults. N Engl J Med 2011;365:506-17. http://dx.doi.org/10.1056/NEJMoa1102662.

[16] Braunschweig CL, Levy P, Sheean PM, Wang X. Enteral compared with parenteral nutrition: a meta-analysis. Am J Clin Nutr 2001;74:534-42.

[17] Heidegger CP, Berger MM, Graf S, Zingg W, Darmon P, Costanza MC, et al. Optimisation of energy provision with supplemental parenteral nutrition in critically ill patients: a randomised controlled clinical trial. Lancet 2013;381: 385-93. http://dx.doi.org/10.1016/S0140-6736(12)61351-8.

[18] Harvey SE, Parrott F, Harrison DA, Bear DE, Segaran E, Beale R, et al. Trial of the route of early nutritional support in critically ill adults. N Engl J Med 2014;371:1673-84. http://dx.doi.org/10.1056/NEJMoa1409860.

[19] Calder PC. Functional roles of fatty acids and their effects on human health. J Parenter Enteral Nutr 2015;39:18S-32S. http://dx.doi.org/10.1177/ 0148607115595980.

[20] Paulsrud J, Pensler L, Whitten C, Stewart S, Holman R. Essential fatty acid deficiency in infants induced by fat-free intravenous feeding. Am J Clin Nutr 1972;25:897-904.

[21] Wanten GJA, Calder PC. Immune modulation by parenteral lipid emulsions. Am J Clin Nutr 2007:85:1171-84

[22] Calder PC. Long-chain n-3 fatty acids and inflammation: potential application in surgical and trauma patients. Braz J Med Biol Res 2003;36:433-46.

[23] Calder PC. Lipids for intravenous nutrition in hospitalised adult patients: a multiple choice of options. Proc Nutr Soc 2013;72:263-76. http://dx.doi.org/ $10.1017 /$ S0029665113001250.

[24] Tribole E. What happened to do no harm? The issue of dietary omega-6 fatty acids. Prostagl Leukot Essent Fat Acids 2009;80:78-9. http://dx.doi.org/ 10.1016/j.plefa.2008.12.003.

[25] Holman RT. The slow discovery of the importance of omega-3 essential fatty acids in human health. J Nutr 1998;128:427-33.

[26] Sailer D, Muller M. Medium chain triglycerides in parenteral nutrition. J Parenter Enteral Nutr 1981;5:115-9.

[27] Ulrich H, Pastures SM, Katz DP, Kvetan V. Parenteral use of medium-chain triglycerides: a reappraisal. Nutrition 1996;12:231-8. http://dx.doi.org/ 10.1016/S0899-9007(96)00089-6.

[28] Lekka ME, Liokatis S, Nathanail C, Galani V, Nakos G. The impact of intravenous fat emulsion administration in acute lung injury. Am J Respir Crit Care Med 2004;169:638-44. http://dx.doi.org/10.1164/rccm.200305-6200C.

[29] Sala-Vila A, Barbosa V, Calder P. Olive oil in parenteral nutrition. Curr Opin Clin Nutr Metab Care 2007;10:165-74. http://dx.doi.org/10.1097/ MCO.0b013e32802bf787.

[30] Pálová S, Charvat J, Kvapil M. Comparison of soybean oil- and olive oil-based lipid emulsions on hepatobiliary function and serum triacylglycerols level during realimentation. J Int Med Res 2008;36:587-93. http://dx.doi.org/ 10.1177/147323000803600326.

[31] Edward R-R, Innes JK, Marino LV, Calder PC. Influence of different intravenous lipid emulsions on growth, development and laboratory and clinical outcomes in hospitalised paediatric patients: a systematic review. Clin Nutr 2017. http://dx.doi.org/10.1016/j.clnu.2017.07.003 (in press).

[32] Carpentier YA, Dupont IE. Advances in intravenous lipid emulsions. World J Surg 2000;24:1493-7. http://dx.doi.org/10.1007/s002680010267.

[33] Hultin M, Müllertz A, Zundel M, Olivecrona G, Hansen T, Deckelbaum R, et al Metabolism of emulsions containing medium- and long-chain triglycerides or interesterified triglycerides. J Lipid Res 1994;35:1850-60.

[34] Simoens C, Deckelbaum RJ, Carpentier YA. Metabolism of defined structured triglyceride particles compared to mixtures of medium and long chain triglycerides intravenously infused in dogs. Clin Nutr 2004;23:665-72. http:// dx.doi.org/10.1016/j.clnu.2003.11.004.
[35] Richelle M, Deckelbaum RJ, Vanweyenberg V, Carpentier YA. Lipoprotein metabolism during and after a 6-h infusion of MCT/LCT vs LCT emulsion in man. Clin Nutr 1997;16:119-23. http://dx.doi.org/10.1016/S0261-5614(97) 80237-3.

[36] Qi K, Seo T, Jiang Z, Carpentier YA, Deckelbaum RJ. Triglycerides in fish oil affect the blood clearance of lipid emulsions containing long- and mediumchain triglycerides in mice. J Nutr 2006;136:2766-72.

[37] Simoens CM, Deckelbaum RJ, Massaut JJ, Carpentier YA. Inclusion of 10\% fish oil in mixed medium-chain triacylglycerol-long-chain triacylglycerol emulsions increases plasma triacylglycerol clearance and induces rapid eicosapentaenoic acid (20:5n-3) incorporation into blood cell phospholipids. Am J Clin Nutr 2008;88:282-8.

[38] Tilley SL, Coffman TM, Koller BH. Mixed messages: modulation of inflammation and immune responses by prostaglandins and thromboxanes. J Clin Investig 2001;108:15-23. http://dx.doi.org/10.1172/JCI13416.

[39] Lewis RA, Austen K, Soberman RJ. Leukotrienes and other products of the 5lipoxygenase pathway: biochemistry and relation to pathobiology in human diseases. N Engl J Med 1990;323:645-55. http://dx.doi.org/10.1056/ NEJM199009063231006.

[40] Vachier I, Chanez P, Bonnans C, Godard P, Bousquet J, Chavis C. Endogenous anti-inflammatory mediators from arachidonate in human neutrophils. Biochem Biophys Res Commun 2002;290:219-24. http://dx.doi.org 10.1006/bbrc.2001.6155.

[41] Bitto A, Minutoli L, David A, Irrera N, Rinaldi M, Venuti FS, et al. Flavocoxid, a dual inhibitor of COX-2 and 5-LOX of natural origin, attenuates the inflammatory response and protects mice from sepsis. Crit Care 2012;16:R32. http://dx.doi.org/10.1186/1364-8535-16-R32.

[42] Walker J, Dichter E, Lacorte G, Kerner D, Spur B, Rodriguez A, et al. Lipoxin A4 increases survival by decreasing systemic inflammation and bacterial load in sepsis. Shock 2011;36:410-6. http://dx.doi.org/10.1097/SHK.0b013e3 $1822798 \mathrm{c} 1$.

[43] Calder PC. Marine omega-3 fatty acids and inflammatory processes: effects, mechanisms and clinical relevance. Biochim Biophys Acta Mol Cell Biol Lipids 2015:1851:469-84. http://dx.doi.org/10.1016/j.bbalip.2014.08.010.

[44] Serhan C, Petasis N. Resolvins and protectins in inflammation resolution. Chem Rev 2011;111:5922-43. http://dx.doi.org/10.1021/cr100396c.

[45] Ott J, Hiesgen C, Mayer K. Lipids in critical care medicine. Prostagl Leukot Essent Fat Acids 2011;85:267-73. http://dx.doi.org/10.1016/j.plefa.2011. 04.011.

[46] Spite M, Norling LV, Summers L, Yang R, Cooper D, Nicos A, et al. Resolvin D2 is a potent regulator of leukocytes and controls microbial sepsis. Nature 2009;461:1287-91. http://dx.doi.org/10.1038/nature08541.

[47] Stanley JC, Elsom RL, Calder PC, Griffin BA, Harris WS, Jebb SA, et al. UK Food Standards Agency Workshop Report: the effects of the dietary n-6:n-3 fatty acid ratio on cardiovascular health. Br J Nutr 2007;98:1305-10. http:/ dx.doi.org/10.1017/S000711450784284X.

[48] Harris WS. The omega-6/omega-3 ratio and cardiovascular disease risk: uses and abuses. Curr Cardiovasc Risk Rep 2007:1:39-45.

[49] McClave SA, Taylor BE, Martindale RG, Warren MM, Johnson DR, Braunschweig $C$, et al. Guidelines for the provision and assessment of nutrition support therapy in the adult critically ill patient: Society of Critical Care Medicine (SCCM) and American Society for Parenteral and Enteral Nutrition (A.S.P.E.N.). J Parenter Enteral Nutr 2016;40:159-211. http:// dx.doi.org/10.1177/0148607115621863.

[50] Dhaliwal R, Cahill N, Lemieux M, Heyland D. The Canadian critical care nutrition guidelines in 2013: an update on current recommendations and implementation strategies. Nutr Clin Pract 2014;29:29-43. http://dx.doi.org/ 10.1177/0884533613510948.

[51] Bernard GR. Acute respiratory distress syndrome. Am J Respir Crit Care Med 2005;172:798-806. http://dx.doi.org/10.1164/rccm.200504-6630E.

[52] ARDS Definition Taskforce, Ranieri V, Rubenfeld G, Thompson B, Ferguson N, Caldwell E, et al. Acute respiratory distress syndrome - the Berlin definition. JAMA 2012;307:1-8. http://dx.doi.org/10.1001/jama.2012.5669.

[53] Bernard GR, Artigas A, Brigham KL, Carlet J, Falke K, Hudson L, et al. Report of the American-European consensus conference on ARDS: definitions, mechanisms, relevant outcomes and clinical trial coordination. Am J Respir Crit Care Med 1994;149:818-24. http://dx.doi.org/10.1007/BF01704707.

[54] Mayer K, Kiessling A, Ott J, Schaefer MB, Hecker M, Henneke I, et al. Acute lung injury is reduced in fat- 1 mice endogenously synthesizing $\mathrm{n}-3$ fatty acids. Am J Respir Crit Care Med 2009;179:474-83. http://dx.doi.org/ 10.1164/rccm.200807-10640C.

[55] Murray M, Kumar M, Gregory T, Banks P, Tazelaar H, DeMichele S. Select dietary fatty acids attenuate cardiopulmonary dysfunction during acute lung injury in pigs. Am J Physiol 1995;269:H2090-9.

[56] Gadek J, DeMichele S, Karlstad M, Pacht E, Donahoe M, Albertson T, et al. Effect of enteral feeding with eicosapentaenoic acid, gamma-linolenic acid, and antioxidants in patients with acute respiratory distress syndrome. Enteral Nutrition in ARDS Study Group. Crit Care Med 1999;27:1409-20.

[57] Singer P, Theilla M, Fisher H, Gibstein L, Grozovski E, Cohen J. Benefit of an enteral diet enriched with eicosapentaenoic acid and gamma-linolenic acid in ventilated patients with acute lung injury. Crit Care Med 2006;34:1033-8. http://dx.doi.org/10.1097/01.CCM.0000206111.23629.0A.

[58] Pontes-Arruda A, Aragao AMA, Albuquerque JD. Effects of enteral feeding with eicosapentaenoic acid, gamma-linolenic acid, and antioxidants in mechanically ventilated patients with severe sepsis and septic shock. Crit 
Care Med 2006;34:2325-33. http://dx.doi.org/10.1097/01.CCM.00002340 33.65657.B6.

[59] Elamin EM, Miller AC, Ziad S. Immune enteral nutrition can improve outcomes in medical-surgical patients with ARDS: a prospective randomized controlled trial. J Nutr Disord Ther 2012;2:109. http://dx.doi.org/10.4172/ 2161-0509.1000109.

[60] Grau-Carmona T, Morán-García V, García-de-Lorenzo A, Heras-de-la-Calle G Quesada-Bellver B, López-Martínez J, et al. Effect of an enteral diet enriched with eicosapentaenoic acid, gamma-linolenic acid and anti-oxidants on the outcome of mechanically ventilated, critically ill, septic patients. Clin Nut 2011;30:578-84. http://dx.doi.org/10.1016/j.clnu.2011.03.004.

[61] Rice TW. Enteral omega-3 fatty acid, $\gamma$-linolenic acid, and antioxidant supplementation in acute lung injury. JAMA 2011;306:1574. http://dx.doi.org/ 10.1001/jama.2011.1435.

[62] Stapleton RD, Martin TR, Weiss NS, Crowley J, Gundel SJ, Nathens AB, et al. A phase II randomized placebo-controlled trial of omega- 3 fatty acids for the treatment of acute lung injury. Crit Care Med 2011;39:1655-62. http:|| dx.doi.org/10.1097/CCM.0b013e318218669d.A.

[63] Felbinger T, Weigand M, Mayer K. Supplementation in acute lung injury. JAMA 2012:307:144. http://dx.doi.org/10.1001/jama.2011.1985.

[64] Zhu D, Zhang Y, Li S, Gan L, Feng H, Nie W. Enteral omega-3 fatty acid supplementation in adult patients with acute respiratory distress syndrome: a systematic review of randomized controlled trials with meta-analysis and trial sequential analysis. Intensive Care Med 2014;40:504-12. http:/ dx.doi.org/10.1007/s00134-014-3244-5.

[65] Glenn JOH, Wischmeyer PE. Enteral fish oil in critical illness: perspectives and systematic review. Curr Opin Clin Nutr Metab Care 2014;17:116-23. http://dx.doi.org/10.1097/MCO.0000000000000039.

[66] Russell J. Management of sepsis. N Engl J Med 2006;355:1699-713. http:// dx.doi.org/10.1056/NEJMra043632.

[67] Rhodes A, Evans LE, Alhazzani W, Levy MM, Antonelli M, Ferrer R, et al. Surviving sepsis campaign: international guidelines for management of sepsis and septic shock: 2016. Intensive Care Med 2017;43:304-77. http:// dx.doi.org/10.1007/s00134-017-4683-6.

[68] Pontes-Arruda A, Martins L, de Lima S, Isola A, Toledo D, Rezende E, et al. Enteral nutrition with eicosapentaenoic acid, $\gamma$-linolenic acid and antioxidants in the early treatment of sepsis: results from a multicenter, prospective, randomized, double-blinded, controlled study: the INTERSEPT Study. Crit Care 2011;15:R144. http://dx.doi.org/10.1186/cc10267.

[69] Braga M. Nutritional approach in malnourished surgical patients: a prospective randomized study. Arch Surg 2002;137:174-80. http://dx.doi.org 10.1001/archsurg.137.2.174.

[70] Klek S, Sierzega M, Szybinski P, Szczepanek K, Scislo L, Walewska E, et al. The immunomodulating enteral nutrition in malnourished surgical patients - a prospective, randomized, double-blind clinical trial. Clin Nutr 2011;30: 282-8. http://dx.doi.org/10.1016/j.clnu.2010.10.001.

[71] Kagan I, Cohen J, Stein M, Bendavid I, Pinsker D, Silva V, et al. Preemptive enteral nutrition enriched with eicosapentaenoic acid, gamma-linolenic acid and antioxidants in severe multiple trauma: a prospective, randomized, double-blind study. Intensive Care Med 2015;41:460-9. http://dx.doi.org 10.1007/s00134-015-3646-z.

[72] Silva V, Singer P. Membrane fatty acid composition of different target populations: importance of baseline on supplementation. Clin Nutr Exp 2015;1: 1-9. http://dx.doi.org/10.1016/j.yclnex.2015.07.001.

[73] van Zanten ARH, Sztark F, Kaisers UX, Zielmann S, Felbinger TW, Sablotzki AR, et al. High-protein enteral nutrition enriched with immunemodulating nutrients vs standard high-protein enteral nutrition and nosocomial infections in the ICU: a randomized clinical trial. JAMA 2014;312: 514-24. http://dx.doi.org/10.1001/jama.2014.7698.

[74] Heyland D, Muscedere J, Wischmeyer PE, Cook D, Jones G, Albert M, et al. A randomized trial of glutamine and antioxidants in critically ill patients. N Engl J Med 2013;368:1489-97. http://dx.doi.org/10.1056/NEJMoa1212722.

[75] Smirniotis V, Kostopanagiotou G, Vassiliou J, Arkadopoulos N, Vassiliou P Datsis A, et al. Long chain versus medium chain lipids in patients with ARDS effects on pulmonary haemodynamics and gas exchange. Intensive Care Med 1998;24:1029-33. http://dx.doi.org/10.1007/s001340050711.

[76] McCray S, Parrish CR. When Chyle leaks: nutrition management options. Pract Gastroenterol 2004;May:60-76.

[77] Furukawa K, Yamamori H, Takagi K, Hayashi N, Suzuki R, Nakajima N, et al. Influences of soybean oil emulsion on stress response and cell-mediated immune function in moderately or severely stressed patients. Nutrition 2002;18:235-40. http://dx.doi.org/10.1016/S0899-9007(01)00784-5.

[78] Battistella F, Widergren J, Anderson J, Siepler J, Weber J, MacColl K. A prospective, randomized trial of intravenous fat emulsion administration in trauma victims requiring total parenteral nutrition. J Trauma 1997;43 $52-8$.

[79] Adolph M, Heller A, Koch T, Koletzko B, Kreymann K, Krohn K, et al. Lipidemulsionen. Aktuel Ernaehr Med 2007;32:S22-9. http://dx.doi.org 10.1055/s-2006-951866.

[80] Adolph M, Heller AR, Koch T, Koletzko B, Kreymann KG, Krohn K, et al. Working group for developing the guidelines for parenteral nutrition of The German Association for Nutritional Medicine. Ger Med Sci 2009;7:1-13. http://dx.doi.org/10.3205/000081.

[81] Masini J, Fichelle A, Pescio M, Bdrdziat G, Desmonts J, Lienhart A. Tolerance clinique et biologique et effets sur les parametrès lipidiques de ClinOléic

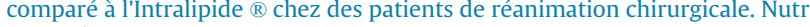
Clin Métab 1996;10:21-4.

[82] Puiggròs C, Sánchez J, Chacón P, Sabín P, Roselló J, Bou R, et al. Evolution of lipid profile, liver function, and pattern of plasma fatty acids according to the type of lipid emulsion administered in parenteral nutrition in the early postoperative period after digestive surgery. J Parenter Enteral Nutr 2009;33:501-12. http://dx.doi.org/10.1038/sj.ejcn.1601961.

[83] Demirer S, Sapmaz A, Karaca AS, Kepenekci I, Aydintug S, Balci D, et al. Effects of postoperative parenteral nutrition with different lipid emulsions in patients undergoing major abdominal surgery. Ann Surg Treat Res 2016;91: 309-15. http://dx.doi.org/10.4174/astr.2016.91.6.309.

[84] Umpierrez GE, Spiegelman R, Zhao V, Dawn D, Pinzon I, Griffith DP, et al. A double-blind, randomized clinical trial comparing soybean oil-based versus olive oil-based lipid emulsions in adult medical-surgical intensive care unit patients requiring parenteral nutrition. Crit Care Med 2012;40: 1792-8. http://dx.doi.org/10.1097/CCM.0b013e3182474bf9.A.

[85] Mateu-de Antonio J, Grau S, Luque S, Marín-Casino M, Albert I, Ribes E. Comparative effects of olive oil-based and soyabean oil-based emulsions on infection rate and leucocyte count in critically ill patients receiving parenteral nutrition. $\mathrm{Br}$ J Nutr 2008;99:846-54. http://dx.doi.org/10.1017/ S0007114507837433.

[86] Grau T, Ruiz de Adana J, Zubillaga S, Fuerte S, Girón C. Randomized study of two different fat emulsions in total parenteral nutrition of malnourished surgical patients; effect of infectious morbidity and mortality. Nutr Hosp 2003;18:159-66.

[87] Marsili I, Iovinelli G, Varrassi G. Parenteral nutrition in COPD patients: longvs medium-chain triglycerides (MCT). Clin Nutr 1992:11:45.

[88] Gopinath R, Yelliboina S, Singh M, Prasad VBN. Impact of supplementing preoperative intravenous omega 3 fatty acids in fish oil on immunomodulation in elderly patients undergoing hip surgery. Indian J Surg 2012;75:1-7. http://dx.doi.org/10.1007/s12262-012-0543-3.

[89] Berger M, Delodder F, Liaudet L, Tozzi P, Schlaepfer J, Chiolero R, et al. Three short perioperative infusions of n23 PUFAs reduce systemic inflammation induced by cardiopulmonary bypass surgery: a randomized controlled trial. Am J Clin Nutr 2013;97:246-54. http://dx.doi.org/10.3945/ajcn.112.046573.1.

[90] Weiss G, Meyer F, Matthies B, Pross M, Koenig W, Lippert H. Immunomodulation by perioperative administration of $\mathrm{n}-3$ fatty acids. $\mathrm{Br} \mathrm{J}$ Nutr 2002;87:S89-94. http://dx.doi.org/10.1079/BJN2001461.

[91] Jiang ZM, Wilmore DW, Wang XR, Wei JM, Zhang ZT, Gu ZY, et al. Randomized clinical trial of intravenous soybean oil alone versus soybean oil plus fish oil emulsion after gastrointestinal cancer surgery. Br J Surg 2010;97: 804-9. http://dx.doi.org/10.1002/bjs.6999.

[92] De Miranda Torrinhas RSM, Santana R, Garcia T, Cury-Boaventura MF, Sales MM, Curi R, et al. Parenteral fish oil as a pharmacological agent to modulate post-operative immune response: a randomized, double-blind, and controlled clinical trial in patients with gastrointestinal cancer. Clin Nutr 2013;32:503-10. http://dx.doi.org/10.1016/j.clnu.2012.12.008.

[93] Zhu M, Tang D, Hou J, Wei J, Hua B, Sun J, et al. Impact of fish oil enriched total parenteral nutrition on elderly patients after colorectal cancer surgery. Chin Med J 2012;125:178-81.

[94] Kłek S, Kulig J, Szczepanik AM, Jedrys J, Kołodziejczyk P. The clinical value of parenteral immunonutrition in surgical patients. Acta Chir Belg 2005;105: 175-9.

[95] Badía-Tahull MB, Llop-Talaverón JM, Leiva-Badosa E, Biondo S, FarranTeixidó L, Ramón-Torrell JM, et al. A randomised study on the clinical progress of high-risk elective major gastrointestinal surgery patients treated with olive oil-based parenteral nutrition with or without a fish oil supplement. Br J Nutr 2010;104:737-41. http://dx.doi.org/10.1017/S0007114510001066.

[96] Wichmann MW, Thul P, Czarnetzki H-D, Morlion BJ, Kemen M, Jauch K-W. Evaluation of clinical safety and beneficial effects of a fish oil containing lipid emulsion (Lipoplus, MLF541): data from a prospective, randomized, multicenter trial. Crit Care Med 2007;35:700-6. http://dx.doi.org/10.1097/ 01.CCM.0000257465.60287.AC.

[97] Grimm H, Mertes N, Goeters C, Schlotzer E, Mayer K, Grimminger F, et al. Improved fatty acid and leukotriene pattern with a novel lipid emulsion in surgical patients. Eur J Nutr 2006;45:55-60. http://dx.doi.org/10.1007/ s00394-005-0573-8.

[98] Zhu XH, Wu YF, Qiu YD, Jiang CP, Ding YT. Liver-protecting effects of omega3 fish oil lipid emulsion in liver transplantation. World J Gastroenterol 2012;18:6141-7. http://dx.doi.org/10.3748/wjg.v18.i42.6141.

[99] Heidt MC, Vician M, Stracke SK, Stadlbauer T, Grebe MT, Boening A, et al. Beneficial effects of intravenously administered N-3 fatty acids for the prevention of atrial fibrillation after coronary artery bypass surgery: a prospective randomized study. Thorac Cardiovasc Surg 2009;57:276-80. http:// dx.doi.org/10.1055/s-0029-1185301.

[100] Tsekos E, Reuter C, Stehle P, Boeden G. Perioperative administration of parenteral fish oil supplements in a routine clinical setting improves patient outcome after major abdominal surgery. Clin Nutr 2004;23:325-30. http:// dx.doi.org/10.1016/j.clnu.2003.07.008.

[101] Pradelli L, Mayer K, Muscaritoli M, Heller AR. n-3 fatty acid-enriched parenteral nutrition regimens in elective surgical and ICU patients: a meta-analysis. Crit Care 2012;16:R184. http://dx.doi.org/10.1186/cc11668.

[102] Chen B, Zhou Y, Yang P, Wan H, Wu X. Safety and efficacy of fish oil-enriched parenteral nutrition regimen on postoperative patients undergoing major abdominal surgery: a meta-analysis of randomized controlled trials. 
J Parenter Enteral Nutr 2010;34:387-94. http://dx.doi.org/10.1038/ sj.ejcn. 1602230 .

[103] Manzanares W, Langlois PL, Dhaliwal R, Lemieux M, Heyland DK. Intravenous fish oil lipid emulsions in critically ill patients: an updated systematic review and meta-analysis. Crit Care 2015;19:1-15. http://dx.doi.org/ 10.1186/s13054-015-0888-7.

[104] Wang J, Yu JC, Kang WM, Ma ZQ. Superiority of a fish oil-enriched emulsion to medium-chain triacylglycerols/long-chain triacylglycerols in gastrointestinal surgery patients: a randomized clinical trial. Nutrition 2012;28:623-9. http://dx.doi.org/10.1016/j.nut.2011.08.004.

[105] Han Y-Y, Lai S-L, Ko W-J, Chou C-H, Lai H-S. Effects of fish oil on inflammatory modulation in surgical intensive care unit patients. Nutr Clin Pract 2012;27:91-8. http://dx.doi.org/10.1177/0884533611429796.

[106] Heller AR, Rössel T, Gottschlich B, Tiebel O, Menschikowski M, Litz RJ, et al. Omega-3 fatty acids improve liver and pancreas function in postoperative cancer patients. Int J Cancer 2004;111:611-6. http://dx.doi.org/10.1002/ ijc.20291.

[107] Piper S, Schade I, Beschmann R, Maleck W, Boldt J, Röhm K. Hepatocellular integrity after parenteral nutrition: comparison of a fish-oil-containing lipid emulsion with an olive-soybean oil-based lipid emulsion. Eur J Anaesthesiol 2009;26:1076-82.

[108] Ma CJ, Sun LC, Chen FM, Lu CY, Shih YL, Tsai HL, et al. A double-blind randomized study comparing the efficacy and safety of a composite vs a conventional intravenous fat emulsion in postsurgical gastrointestinal tumor patients. Nutr Clin Pract 2012;27:410-5. http://dx.doi.org/10.1177/ 0884533611436115.

[109] Metry AA, Abdelaal W, Ragaei M, Refaat M, Nakhla G. SMOFlipid versus intralipid in postoperative ICU patients. Enliven J Anesthesiol Crit Care Med 2014;1:15.

[110] Wu M-H, Wang M-Y, Yang C-Y, Kuo M-L, Lin M-T. Randomized clinical trial of new intravenous lipid (SMOFlipid 20\%) versus medium-chain triglycerides/long-chain triglycerides in adult patients undergoing gastrointestinal surgery. J Parenter Enteral Nutr 2014;38:800-8. http://dx.doi.org/ 10.1177/0148607113512869.

[111] Tian H, Yao X, Zeng R, Sun R, Tian H, Shi C, et al. Safety and efficacy of a new parenteral lipid emulsion (SMOF) for surgical patients: a systematic review and meta-analysis of randomized controlled trials. Nutr Rev 2013;71: 815-21. http://dx.doi.org/10.1111/nure.12053.

[112] Von Schacky C, Fischer S, Weber PC. Long-term effects of dietary marine omega-3 fatty-acids upon plasma and cellular lipids, platelet-function, and eicosanoid formation in humans. J Clin Investig 1985;76:1626-31. http:// dx.doi.org/10.1172/Jci112147.

[113] Veljovic M, Mihajlovic I, Subota V, Antunovic M, Jevdjic J, Udovicic I, et al. Effect of pretreatment with omega-3 polyunsaturated fatty acids (PUFAs) on hematological parameters and platelets aggregation in patients during elective coronary artery bypass grafting. Vojnosanit Pregl 2013;70:396-402. http://dx.doi.org/10.2298/VSP1304396V.

[114] Weimann A, Braga M, Carli F, Higashiguchi T, Hübner M, Klek S, et al. ESPEN guideline: clinical nutrition in surgery. Clin Nutr 2017. http://dx.doi.org/ 10.1016/j.clnu.2017.02.013.

[115] Edmunds C, Brody R, Parrott J, Stankorb S, Heyland D. The effects of different IV fat emulsions on clinical outcomes in critically ill patients. Crit Care Med 2014;42:1168-77. http://dx.doi.org/10.1097/CCM.0000000000000146.

[116] Wang X, Li W, Li N, Li J. $\omega-3$ Fatty acids-supplemented parenteral nutrition decreases hyperinflammatory response and attenuates systemic disease sequelae in severe acute pancreatitis: a randomized and controlled study. J Parenter Enteral Nutr 2008;32:236-41. http://dx.doi.org/10.1177/ 0148607108316189.

[117] Mayer K, Fegbeutel C, Hattar K, Sibelius U, Krämer HJ, Heuer KU, et al. $\omega-3$ vs. $\omega-6$ lipid emulsions exert differential influence on neutrophils in septic shock patients: impact on plasma fatty acids and lipid mediator generation. Intensive Care Med 2003;29:1472-81. http://dx.doi.org/10.1007/s00134003-1900-2.

[118] Hall TC, Bilku DK, Al-Leswas D, Neal CP, Horst C, Cooke J, et al. A randomized controlled trial investigating the effects of parenteral fish oil on survival outcomes in critically ill patients with sepsis: a pilot study. J Parenter Enteral Nutr 2015;39:301-12. http://dx.doi.org/10.1177/0148607113518945.

[119] Barbosa VM, Miles EA, Calhau C, Lafuente E, Calder PC. Effects of a fish oil containing lipid emulsion on plasma phospholipid fatty acids, inflammatory markers, and clinical outcomes in septic patients: a randomized, controlled clinical trial. Crit Care 2010;14:R5. http://dx.doi.org/10.1186/cc8844.

[120] Burkhart CS, Dell-Kuster S, Siegemund M, Pargger H, Marsch S, Strebel SP, et al. Effect of n-3 fatty acids on markers of brain injury and incidence of sepsis-associated delirium in septic patients. Acta Anaesthesiol Scand 2014;58:689-700. http://dx.doi.org/10.1111/aas.12313.

[121] Khor B-S, Liaw S-J, Shih H-C, Wang L-S. Randomized, double blind, placebocontrolled trial of fish-oil-based lipid emulsion infusion for treatment of critically ill patients with severe sepsis. Asian J Surg 2011;34:1-10. http:// dx.doi.org/10.1016/S1015-9584(11)60011-0.

[122] Mayer K, Gokorsch S, Fegbeutel C, Hattar K, Rosseau S, Walmrath D, et al Parenteral nutrition with fish oil modulates cytokine response in patients with sepsis. Am J Respir Crit Care Med 2003;167:1321-8. http://dx.doi.org/ 10.1164/rccm.200207-6740C.

[123] Grau-Carmona T, Bonet-Saris A, García-de-Lorenzo A, Sánchez-Alvarez C, Rodríguez-Pozo A, Acosta-Escribano J, et al. Influence of n-3 polyunsaturated fatty acids enriched lipid emulsions on nosocomial infections and clinical outcomes in critically ill patients: ICU lipids study. Crit Care Med 2015;43: 1-9. http://dx.doi.org/10.1097/CCM.0000000000000612.

[124] Chen W, Jiang H, Zhou Z, Tao Y, Cai B, Liu J, et al. Is omega-3 fatty acids enriched nutrition support safe for critical ill patients? A systematic review and meta-analysis. Nutrients 2014;6:2148-64. http://dx.doi.org/10.3390/ nu6062148.

[125] Palmer AJ, Ho CKM, Ajibola O, Avenell A. The role of $\omega-3$ fatty acid supplemented parenteral nutrition in critical illness in adults. Crit Care Med 2013;41:307-16. http://dx.doi.org/10.1097/CCM.0b013e3182657578.

[126] Friesecke S, Lotze C, Köhler J, Heinrich A, Felix SB, Abel P. Fish oil supplementation in the parenteral nutrition of critically ill medical patients: a randomised controlled trial. Intensive Care Med 2008;34:1411-20. http:/ dx.doi.org/10.1007/s00134-008-1072-1.

[127] Heller AR, Rössler S, Litz RJ, Stehr SN, Heller SC, Koch R, et al. Omega-3 fatty acids improve the diagnosis-related clinical outcome. Crit Care Med 2006;34:972-9. http://dx.doi.org/10.1097/01.CCM.0000206309.83570.45.

[128] Koletzko B, Goulet O, Hunt J, Krohn K, Shamir R. Guidelines on paediatric parenteral nutrition of the European Society of Paediatric Gastroenterology, Hepatology and Nutrition (ESPGHAN) and the European Society for Clinical Nutrition and Metabolism (ESPEN). J Pediatr Gastroenterol Nutr 2005;41(Suppl 2):S1-87. http://dx.doi.org/10.1097/01.mpg.0000181841.07090.f4.

[129] Lapillonne A, Kermorvant-duchemin E. A systematic review of practice surveys on parenteral nutrition for preterm infants. J Nutr 2013:2061S-5S. http://dx.doi.org/10.3945/jn.113.176982.2061S.

[130] Uthaya S, Modi N. Practical preterm parenteral nutrition: systematic literature review and recommendations for practice. Early Hum Dev 2014;90: 747-53. http://dx.doi.org/10.1016/j.earlhumdev.2014.09.002.

[131] Calder PC. Docosahexaenoic acid. Ann Nutr Metab 2016;69:8-21. http:// dx.doi.org/10.1159/000448262.

[132] Vlaardingerbroek H, Veldhorst MAB, Spronk S, Van Den Akker CHP, Van Goudoever JB. Parenteral lipid administration to very-low-birth-weight infants - early introduction of lipids and use of new lipid emulsions: a systematic review and meta-analysis. Am J Clin Nutr 2012;96:255-68. http:// dx.doi.org/10.3945/ajcn.112.040717.

[133] Vlaardingerbroek H, Vermeulen MJ, Rook D, Van Den Akker CHP, Dorst K, Wattimena JL, et al. Safety and efficacy of early parenteral lipid and highdose amino acid administration to very low birth weight infants. J Pediatr 2013;163:638-44. http://dx.doi.org/10.1016/j.jpeds.2013.03.059. e5.

[134] Roelants JA, Vlaardingerbroek H, van den Akker CHP, de Jonge RCJ, van Goudoever JB, Vermeulen MJ. Two-year follow-up of a randomized controlled nutrition intervention trial in very low-birth-weight infants. J Parenter Enteral Nutr 2016. http://dx.doi.org/10.1177/0148607116678196 (in press).

135] A.S.P.E.N: Board of Directors. Guidelines for the use of parenteral and enteral nutrition in adult and pediatric patients. J Parenter Enteral Nutr 2002;26: 1SA-138SA

[136] Wales PW, De Silva N, Kim J, Lecce L, To T, Moore A. Neonatal short bowel syndrome: population-based estimates of incidence and mortality rates. J Pediatr Surg 2004;39:690-5. http://dx.doi.org/10.1016/j.jpedsurg.2004.01.036.

[137] Diamond IR, Sterescu A, Pencharz PB, Kim JH, Wales PW. Changing the paradigm: Omegaven for the treatment of liver failure in pediatric short bowel syndrome. J Pediatr Gastroenterol Nutr 2009;48:209-15. http:/ dx.doi.org/10.1097/MPG.0b013e318182c8f6.

[138] Wales PW, De Silva N, Kim JH, Lecce L, Sandhu A, Moore AM. Neonatal short bowel syndrome: a cohort study. J Pediatr Surg 2005;40:755-62. http:// dx.doi.org/10.1016/j.jpedsurg.2005.01.037.

[139] Squires RH, Duggan C, Teitelbaum DH, Wales PW, Balint J, Venick R, et al. Natural history of pediatric intestinal failure: initial report from the pediatric intestinal failure consortium. J Pediatr 2012;161:723-8. http://dx.doi.org 10.1016/j.jpeds.2012.03.062. e2.

[140] Beath SV, Davies P, Papadopoulou A, Khan AR, Buick RG, Corkery JJ, et al. Parenteral nutrition-related cholestasis in postsurgical neonates: multivariate analysis of risk factors. J Pediatr Surg 1996;31:604-6. http://dx.doi.org/ 10.1016/S0022-3468(96)90507-2.

[141] Nandivada P, Cowan E, Carlson SJ, Chang M, Gura KM, Puder M. Mechanisms for the effects of fish oil lipid emulsions in the management of parenteral nutrition-associated liver disease. Prostagl Leukot Essent Fat Acids 2013;89: 153-8. http://dx.doi.org/10.1016/j.plefa.2013.02.008.

[142] Salvador A, Janeczko M, Porat R, Sekhon R, Moewes A, Schutzman D. Randomized controlled trial of early parenteral nutrition cycling to prevent cholestasis in very low birth weight infants. J Pediatr 2012;161:229-33. http://dx.doi.org/10.1016/j.jpeds.2012.02.003.

[143] Jensen AR, Goldin AB, Koopmeiners JS, Stevens J, Waldhausen JHT, Kim SS The association of cyclic parenteral nutrition and decreased incidence of cholestatic liver disease in patients with gastroschisis. J Pediatr Surg 2009;44:183-9. http://dx.doi.org/10.1016/j.jpedsurg.2008.10.033.

[144] Rangel SJ, Calkins CM, Cowles RA, Barnhart DC, Huang EY, Abdullah F, et al. Parenteral nutrition-associated cholestasis: an American pediatric surgical association outcomes and clinical trials committee systematic review. J Pediatr Surg 2012;47:225-40. http://dx.doi.org/10.1016/j.jpedsurg.2011.10.007.

[145] Kubota A, Okada A, Imura K, Kawahara H, Nezu R, Kamata S, et al. The effect of metronidazole on TPN-associated liver dysfunction in neonates. J Pediatr Surg 1990;25:618-21.

[146] Srivastava B, Gimson A. Hepatic changes in systemic infection. Best Pract Res Clin Gastroenterol 2013;27:485-95. http://dx.doi.org/10.1016/j.bpg.2013.06.011. 
[147] Cober MP, Killu G, Brattain A, Welch KB, Kunisaki SM, Teitelbaum DH. Intravenous fat emulsions reduction for patients with parenteral nutritionassociated liver disease. J Pediatr 2012;160:421-7. http://dx.doi.org 10.1016/j.jpeds.2011.08.047.

[148] Rollins MD, Ward RM, Jackson WD, Mulroy CW, Spencer CP, Ying J, et al. Effect of decreased parenteral soybean lipid emulsion on hepatic function in infants at risk for parenteral nutrition-associated liver disease: a pilot study. J Pediatr Surg 2013;48:1348-56. http://dx.doi.org/10.1016/j.jpedsurg.2013.03.040.

[149] Sanchez SE, Braun LP, Mercer LD, Sherrill M, Stevens J, Javid PJ. The effect of lipid restriction on the prevention of parenteral nutrition-associated cholestasis in surgical infants. J Pediatr Surg 2013;48:573-8. http://dx.doi.org/ 10.1016/j.jpedsurg.2012.08.016.

[150] Muhammed R, Bremner R, Protheroe S, Johnson T, Holden C, Murphy MS Resolution of parenteral nutrition-associated jaundice on changing from a soybean oil emulsion to a complex mixed-lipid emulsion. J Pediatr Gastroenterol Nutr 2012;54:797-802. http://dx.doi.org/10.1097/MPG.0b 013e3182447daf.

[151] Attard M, Patel N, Simpson J. Change from intralipid to SMOF lipid is associated with improved liver function in infants with PN associated liver dis ease. Arch Dis Child 2012;97:A54-5.

[152] Orso G, Mandato C, Veropalumbo C, Cecchi N, Garzi A, Vajro P. Pediatric parenteral nutrition-associated liver disease and cholestasis: novel advances in pathomechanisms-based prevention and treatment. Dig Liver Dis 2016;48:215-22. http://dx.doi.org/10.1016/j.dld.2015.11.003.

[153] Chan S, McCowen KC, Bistrian BR, Thibault A, Keane-Ellison M, Forse RA, et al. Incidence, prognosis, and etiology of end-stage liver disease in patients receiving home total parenteral nutrition. Surgery 1999;126:28-34. http:/ dx.doi.org/10.1067/msy.1999.98925.

[154] Beath SV, Kelly DA. Total parenteral nutrition-induced cholestasis: prevention and management. Clin Liver Dis 2016;20:159-76. http://dx.doi.org/ 10.1016/j.cld.2015.08.009.

[155] Carter BA, Taylor OA, Prendergast DR, Zimmerman TL, Von Furstenberg R, Moore DD, et al. Stigmasterol, a soy lipid-derived phytosterol, is an antagonist of the bile acid nuclear receptor FXR. Pediatr Res 2007;62:301-6 http://dx.doi.org/10.1203/PDR.0b013e3181256492.

[156] Nandivada P, Fell GL, Gura KM, Puder M. Lipid emulsions in the treatment and prevention of parenteral nutrition - associated liver disease in infants and children. Am J Clin Nutr 2016;103:629-35. http://dx.doi.org/10.3945/ ajcn.114.103986.1.

[157] de Meijer V, Gura K, Meisel J, Le H, Puder M. Parenteral fish oil monotherapy in the management of patients with parenteral nutrition-associated liver disease. Arch Surg 2010;145:547. http://dx.doi.org/10.1001/archsurg.2010.80.

[158] Vlaardingerbroek H, Vermeulen M, Carnielli V, Vaz F, van den Akker C, van Goudoever J. Growth and fatty acid profiles of VLBW infants receiving a multicomponent lipid emulsion from birth. J Pediatr Gastroenterol Nut 2014;58:417-27. http://dx.doi.org/10.1097/MPG.0000000000000280.

[159] Beken S, Dilli D, Fettah ND, Kabataş EU, Zenciroğlu A, Okumuş N. The influence of fish-oil lipid emulsions on retinopathy of prematurity in very low birth weight infants: a randomized controlled trial. Early Hum Dev 2014;90: 27-31. http://dx.doi.org/10.1016/j.earlhumdev.2013.11.002.

[160] D'Ascenzo R, Savini S, Biagetti C, Bellagamba MP, Marchionni P, Pompilio A et al. Higher docosahexaenoic acid, lower arachidonic acid and reduced lipid tolerance with high doses of a lipid emulsion containing $15 \%$ fish oil: a randomized clinical trial. Clin Nutr 2014;33:1002-9. http://dx.doi.org/ 10.1016/j.clnu.2014.01.009.

[161] Deshpande G, Simmer K, Deshmukh M, Mori TA, Croft KD, Kristensen J. Fish oil (SMOFlipid) and olive oil lipid (Clinoleic) in very preterm neonates. J Pediatr Gastroenterol Nutr 2014;58:177-82. http://dx.doi.org/10.1097/ MPG.0000000000000174.

[162] Pawlik D, Lauterbach R, Walczak M, Hurkała J, Sherman MP. Fish-oil fat emulsion supplementation reduces the risk of retinopathy in very low birth weight infants: a prospective, randomized study. J Parenter Enteral Nutr 2013;38:711-6. http://dx.doi.org/10.1177/0148607113499373.

[163] Savini S, D'Ascenzo R, Biagetti C, Serpentini G, Pompilio A, Bartoli A, et al. The effect of 5 intravenous lipid emulsions on plasma phytosterols in preterm infants receiving parenteral nutrition: a randomized clinical trial. Am J Clin Nutr 2013;98:312-8. http://dx.doi.org/10.3945/ajcn.112.056556.

[164] Wang Y, Zhou K-J, Tang Q-Y, Hong L, Feng Y, Lu L-N, et al. Effect of an olive oil-based lipid emulsion compared with a soybean oil-based lipid emulsion on liver chemistry and bile acid composition in preterm infants receiving parenteral nutrition: a double-blind, randomized trial. J Parenter Enteral Nutr 2016;40:842-50. http://dx.doi.org/10.1177/0148607114566853.

[165] Larsen BMK, Field CJ, Leong AY, Goonewardene LA, Van Aerde JE, Joffe AR, et al. Pretreatment with an intravenous lipid emulsion increases plasma eicosapentanoic acid and downregulates leukotriene B4, procalcitonin, and lymphocyte concentrations after open heart surgery in infants. J Parenter Enteral Nutr 2015;39:171-9. http://dx.doi.org/10.1177/0148607113505326.

[166] Larsen BMK, Goonewardene LA, Joffe AR, Van Aerde JE, Field CJ, Olstad DL, et al. Pre-treatment with an intravenous lipid emulsion containing fish oil (eicosapentaenoic and docosahexaenoic acid) decreases inflammatory markers after open-heart surgery in infants: a randomized, controlled trial. Clin Nutr 2012;31:322-9. http://dx.doi.org/10.1016/j.clnu.2011.11.006.

[167] Pradelli L, Eandi M, Povero M, Mayer K, Muscaritoli M, Heller AR, et al. Costeffectiveness of omega-3 fatty acid supplements in parenteral nutrition therapy in hospitals: a discrete event simulation model. Clin Nutr 2014;33: 785-92. http://dx.doi.org/10.1016/j.clnu.2013.11.016.

[168] UK spinal cord injury statistics. www.apparelyzed.com/statistics.html.

[169] Aarabi B, Simard JM, Kufera JA, Alexander M, Zacherl KM, Mirvis SE, et al. Intramedullary lesion expansion on magnetic resonance imaging in patients with motor complete cervical spinal cord injury. J Neurosurg Spine 2012;17: 243-50. http://dx.doi.org/10.3171/2012.6.SPINE12122.

[170] Huang WL, George KJ, Ibba V, Liu MC, Averill S, Quartu M, et al. The characteristics of neuronal injury in a static compression model of spinal cord injury in adult rats. Eur J Neurosci 2007;25:362-72. http://dx.doi.org/ 10.1111/j.1460-9568.2006.05284.x.

[171] Priestley J, Michael-Titus A, Tetzlaff W. Limiting spinal cord injury by pharmacological intervention. Handb Clin Neurol 2012;109:463-84. http:// dx.doi.org/10.1016/B978-0-444-52137-8.00029-2.

[172] Huang WL, King VR, Curran OE, Dyall SC, Ward RE, Lal N, et al. A combination of intravenous and dietary docosahexaenoic acid significantly improves outcome after spinal cord injury. Brain 2007;130:3004-19. http:// dx.doi.org/10.1093/brain/awm223.

[173] King VR. Omega-3 fatty acids improve recovery, whereas omega-6 fatty acids worsen outcome, after spinal cord injury in the adult rat. J Neurosci 2006;26: 4672-80. http://dx.doi.org/10.1523/JNEUROSCI.5539-05.2006.

[174] Lim S-N, Huang W, Hall JCE, Michael-Titus AT, Priestley JV. Improved outcome after spinal cord compression injury in mice treated with docosahexaenoic acid. Exp Neurol 2013;239:13-27. http://dx.doi.org/10.1016/ j.expneurol.2012.09.015.

[175] Pallier PN, Poddighe L, Zbarsky V, Kostusiak M, Choudhury R, Hart T, et al. A nutrient combination designed to enhance synapse formation and function improves outcome in experimental spinal cord injury. Neurobiol Dis 2015;82:504-15. http://dx.doi.org/10.1016/j.nbd.2015.09.007.

[176] Paterniti I, Impellizzeri D, Di Paola R, Esposito E, Gladman S, Yip P, et al. Docosahexaenoic acid attenuates the early inflammatory response following spinal cord injury in mice: in-vivo and in-vitro studies. J Neuroinflamm 2014;11:6. http://dx.doi.org/10.1186/1742-2094-11-6.

[177] Liu Z-H, Yip PK, Adams L, Davies M, Lee JW, Michael GJ, et al. A single bolus of docosahexaenoic acid promotes neuroplastic changes in the innervation of spinal cord interneurons and motor neurons and improves functional recovery after spinal cord injury. J Neurosci 2015;35:12733-52. http:// dx.doi.org/10.1523/JNEUROSCI.0605-15.2015.

[178] National Center for Injury Prevention and Control. https://www.cdc.gov/ traumaticbraininjury/get_the_facts.html.

[179] Uryu K, Laurer H, McIntosh T, Praticò D, Martinez D, Leight S, et al. Repetitive mild brain trauma accelerates amyloid-beta deposition, lipid peroxidation, and cognitive impairment in a transgenic mouse model of Alzheimer amyloidosis. J Neurosci 2002;22:446-54. 11784789

[180] Al Omran Y, Angus R, Yip P, Davies M, Giovanonni G, Michael-Titus A. The effects of docosahexaenoic acid in a mouse model of traumatic brain injury. Ann Med Surg 2014;3:19. http://dx.doi.org/10.1016/j.amsu.2014.01.005.

[181] Michael-Titus AT, Priestley JV. Omega-3 fatty acids and traumatic neurological injury: from neuroprotection to neuroplasticity? Trends Neurosci 2014;37:30-8. http://dx.doi.org/10.1016/j.tins.2013.10.005.

[182] Williams JJ, Mayurasakorn K, Vannucci SJ, Mastropietro C, Bazan NG, Ten VS, et al. N-3 fatty acid rich triglyceride emulsions are neuroprotective after cerebral hypoxic-ischemic injury in neonatal mice. PLoS One 2013;8:1-11. http://dx.doi.org/10.1371/journal.pone.0056233.

[183] Belayev L, Khoutorova L, Atkins KD, Eady TN, Hong S, Lu Y, et al. Docosahexaenoic acid therapy of experimental ischemic stroke. Transl Stroke Res 2011;2:33-41. http://dx.doi.org/10.1007/s12975-010-0046-0.

[184] Myer DJ, Gurkoff GG, Lee SM, Hovda DA, Sofroniew MV. Essential protective roles of reactive astrocytes in traumatic brain injury. Brain 2006;129: 2761-72. http://dx.doi.org/10.1093/brain/awl165.

[185] Bardehle S, Krüger M, Buggenthin F, Schwausch J, Ninkovic J, Clevers H, et al. Live imaging of astrocyte responses to acute injury reveals selective juxtavascular proliferation. Nat Neurosci 2013;16:580-6. http://dx.doi.org/ 10.1038/nn.3371.

[186] Roth TL, Nayak D, Atanasijevic T, Koretsky AP, Latour LL, McGavern DB. Transcranial amelioration of inflammation and cell death after brain injury. Nature 2014;505:223-8. http://dx.doi.org/10.1038/nature12808.

[187] Venkatesan C, Chrzaszcz M, Choi N, Wainwright MS. Chronic upregulation of activated microglia immunoreactive for galectin-3/Mac-2 and nerve growth factor following diffuse axonal injury. J Neuroinflamm 2010;7:1-10. http:// dx.doi.org/10.1186/1742-2094-7-32.

[188] Johnson VE, Stewart JE, Begbie FD, Trojanowski JQ Smith DH, Stewart W. Inflammation and white matter degeneration persist for years after a single traumatic brain injury. Brain 2013;136:28-42. http://dx.doi.org/10.1093/ brain/aws322.

[189] Ramlackhansingh AF, Brooks DJ, Greenwood RJ, Bose SK, Turkheimer FE Kinnunen KM, et al. Inflammation after trauma: microglial activation and traumatic brain injury. Ann Neurol 2011;70:374-83. http://dx.doi.org/ 10.1002/ana.22455.

[190] Grimminger F, Wahn H, Mayer K, Kiss L, Walmrath D, Seeger W. Impact of arachidonic versus eicosapentaenoic acid on exotonin-induced lung vascular leakage: relation to 4-series versus 5-series leukotriene generation. Am J Respir Crit Care Med 1997;155:513-9. http://dx.doi.org/10.1164/ ajrccm.155.2.9032187. 
[191] Grimminger F, Mayer K, Kraemer H, Stephens J, Walmrath D, Seeger W. Differential vasoconstrictor potencies of free fatty acids in the lung vasculature. J Pharmacol Exp Ther 1993;267:259-65.

[192] Mayer K, Merfels M, Muhly-Reinholz M, Gokorsch S, Rosseau S, Lohmeyer J, et al. Omega-3 fatty acids suppress monocyte adhesion to human endothelial cells: role of endothelial PAF generation. Am J Physiol Heart Circ Physiol 2002;283:H811-8. http://dx.doi.org/10.1152/ajpheart.00235.2002.

[193] Zimmerman GA, McIntyre TM, Mehra M, Prescott SM. Endothelial cellassociated platelet-activating factor: a novel mechanism for signaling intercellular adhesion. J Cell Biol 1990;110:529-40.

[194] Schaefer M, Ott J, Mohr A, Bi M, Grosz A, Weissmann N, et al. Immunomodulation by $n-3$ - versus $n-6$-rich lipid emulsions in murine acute lung injuryrole of platelet-activating factor receptor. Crit Care Med 2007;35:544-54. http://dx.doi.org/10.1097/01.CCM.0000253811.74112.B6.

[195] Hecker M, Ott J, Sondermann C, Schaefer M, Obert M, Hecker A, et al. Immunomodulation by fish-oil containing lipid emulsions in murine acute respiratory distress syndrome. Crit Care 2014;18:R85. http://dx.doi.org/10.1186/cc13850.

[196] Hotchkiss R, Swanson P, Freeman B, Tinsley K, Cobb J, Matuschak G, et al. Apoptotic cell death in patients with sepsis, shock, and multiple organ dysfunction. Crit Care Med 1999;27:1230-51.

[197] Bi MH, Ott J, Fischer T, Hecker M, Dietrich H, Schaefer MB, et al. Induction of lymphocyte apoptosis in a murine model of acute lung injury-modulation by lipid emulsions. Shock 2010;33:179-88. http://dx.doi.org/10.1097/ SHK.0b013e3181ac4b3b.

[198] Pscheidl E, Schywalsky M, Tschaikowsky K, Böke-Pröls T. Fish oilsupplemented parenteral diets normalize splanchnic blood flow and improve killing of translocated bacteria in a low-dose endotoxin rat model. Crit Care Med 2000;28:1489-96.

[199] Mayer K, Meyer S, Reinholz-Muhly M, Maus U, Merfels M, Lohmeyer J, et al. Short-time infusion of fish oil-based lipid emulsions, approved for parenteral nutrition, reduces monocyte proinflammatory cytokine generation and adhesive interaction with endothelium in humans. J Immunol 2003;171: 4837-43. http://dx.doi.org/10.4049/jimmunol.171.9.4837.

[200] Pluess TT, Hayoz D, Berger MM, Tappy L, Revelly JP, Michaeli B, et al. Intravenous fish oil blunts the physiological response to endotoxin in healthy subjects. Intensive Care Med 2007;33:789-97. http://dx.doi.org/ 10.1007/s00134-007-0591-5.

[201] Hecker M, Linder T, Ott J, Walmrath H-D, Lohmeyer J, Vadász I, et al. Immunomodulation by lipid emulsions in pulmonary inflammation: a randomized controlled trial. Crit Care 2015;19:226. http://dx.doi.org/10.1186/ s13054-015-0933-6.

[202] Marik PE, Zaloga GP. Immunonutrition in critically ill patients: a systematic review and analysis of the literature. Intensive Care Med 2008;34:1980-90. http://dx.doi.org/10.1007/s00134-008-1213-6.
[203] Calder PC, Jensen GL, Koletzko BV, Singer P, Wanten GJA. Lipid emulsions in parenteral nutrition of intensive care patients: current thinking and future directions. Intensive Care Med 2010;36:735-49. http://dx.doi.org/10.1007/ s00134-009-1744-5.

[204] Driscoll DF, Ling PR, Bistrian BR. Pharmacopeial compliance of fish oilcontaining parenteral lipid emulsion mixtures: globule size distribution (GSD) and fatty acid analyses. Int J Pharm 2009;379:125-30. http:// dx.doi.org/10.1016/j.ijpharm.2009.06.021.

[205] Xu Z, Harvey K, Pavlina T, Dutot G, Zaloga G, Siddiqui R. An improved method for determining medium- and long-chain FAMEs using gas chromatography. Lipids 2010;45:199-208. http://dx.doi.org/10.1007/s11745-009-3382-7.

[206] Berger MM, Tappy L, Revelly JP, Koletzko BV, Gepert J, Corpataux JM, et al. Fish oil after abdominal aorta aneurysm surgery. Eur J Clin Nutr 2008;62: 1116-22. http://dx.doi.org/10.1038/sj.ejcn.1602817.

[207] Wachtler P, Konig W, Senkal M, Kemen M, Koller M. Influence of a tota parenteral nutrition enriched with omega-3 fatty acids on leukotriene synthesis of peripheral leukocytes and systemic cytokine levels in patients with major surgery. J Trauma Inj Infect Crit Care 1997;42:191-8.

[208] Barros KV, Cassulino AP, Schalch L, Della Valle Munhoz E, Manetta JA, Noakes PS, et al. Supplemental intravenous n-3 fatty acids and n-3 fatty acid status and outcome incritically ill elderly patients in the ICU receiving enteral nutrition. Clin Nutr 2013;32:599-605. http://dx.doi.org/10.1016/ j.clnu.2012.10.016.

[209] Barros KV, Cassulino AP, Schalch L, Della Valle Munhoz E, Manetta JA Calder PC, et al. Pharmaconutrition: acute fatty acid modulation of circulating cytokines in elderly patients in the ICU. J Parenter Enteral Nutr 2014:38:467-74. http://dx.doi.org/10.1177/0148607113480183.

[210] García-de-Lorenzo A, Denia R, Atlan P, Martinez-Ratero S, Le Brun A, Evard D, et al. Parenteral nutrition providing a restricted amount of linoleic acid in severely burned patients: a randomised double-blind study of an olive oilbased lipid emulsion $\mathrm{v}$. medium/long-chain triacylglycerols. $\mathrm{Br}$ J Nutr 2005;94:221-30. http://dx.doi.org/10.1079/BJN20051467.

[211] Gupta A, Govil D, Bhatnagar S, Gupta S, Goyal J, Patel S, et al. Efficacy and safety of parenteral omega 3 fatty acids in ventilated patients with acute lung injury. Indian J Crit Care Med 2011;15:108-13. http://dx.doi.org/ 10.4103/0972-5229.83019.

[212] Sabater J, Masclans JR, Sacanell J, Chacon P, Sabin P, Planas M. Effects on hemodynamics and gas exchange of omega-3 fatty acid-enriched lipid emulsion in acute respiratory distress syndrome (ARDS): a prospective, randomized, double-blind, parallel group study. Lipids Heal Dis 2008;7:39. http://dx.doi.org/10.1186/1476-511X-7-39. 1476-511X-7-39 [pii]. 